VERA REGINA MONTEIRO DE BARROS

Estudo de fatores de patogenicidade de Bacillus spp isolado em leite UHT 
VERA REGINA MONTEIRO DE BARROS

\section{Estudo de fatores de patogenicidade de Bacillus spp isolado em leite UHT}

Tese apresentada ao Programa de Pós-graduação em Epidemiologia Experimental Aplicada a Zoonoses da Faculdade de Medicina Veterinária e Zootecnia da Universidade de São Paulo para obtenção do título de Doutor em Medicina Veterinária

\section{Departamento:}

Medicina Veterinária Preventiva e

Saúde Animal

Área de Concentração:

Epidemiologia Experimental e Aplicada às Zoonoses

Orientador:

Prof. Dr. José Cezar Panetta

São Paulo 
Autorizo a reprodução parcial ou total desta obra, para fins acadêmicos, desde que citada a fonte.

DADOS INTERNACIONAIS DE CATALOGAÇÃO-NA-PUBLICAÇÃO

(Biblioteca da Faculdade de Medicina Veterinária e Zootecnia da Universidade de São Paulo)

T.1389 Barros, Vera Regina Monteiro de

FMVZ Estudo de fatores de patogenicidade de Bacillus spp isolado em leite UHT / Vera Regina Monteiro de Barros - São Paulo : V. R. M. Barros, 2004.

$116 \mathrm{f}$. : il

Tese (doutorado) - Universidade de São Paulo. Faculdade de Medicina Veterinária e Zootecnia. Departamento de Medicina Veterinária Preventiva e Saúde Animal, 2004.

Programa de Pós-graduação: Epidemiologia Experimental e Aplicada às Zoonoses.

Área de concentração: Epidemiologia Experimental e Aplicada às Zoonoses.

Orientador: Prof. Dr. José Cezar Panetta.

1. Leite. 2. Esporos bacterianos. 3. Patogenia animal. 4. Citotoxinas. I Título. 
ERRATA

$\begin{array}{lllll}\text { Página } & \text { parágrafo } & \text { linha } & \text { onde se lê } & \text { leia-se } \\ 52 & 2 & 4 & \text { ágar padrão } & \text { ágar nutritivo } \\ 104 & 11 & n^{\circ} 451 & n^{\circ} 146 \\ 104 & 14 & 4 \text { set } 1997 & 11 \text { mar } 1996 \\ 108 & 22 & 1989 & 1984\end{array}$




\section{UNIVERSIDADE DE SÃO PAULO \\ Faculdade de Medicina Veterinária e Zootecnia \\ Cidade Universitária "Armando de Salles Oliveira" Comissão Bioética \\ CERTIFICADO}

Certificamos que o Projeto intitulado "Fatores de patogenicidade de Bacillus spp isolado em Leite UHT", Protocolo n¹73/2002, utilizando 100 camundongos e 10 coelhos, sob a responsabilidade do Prof. Dr. José Cezar Panetta, está de acordo com os princípios éticos de experimentação animal da Comissão de Bioética da Faculdade de Medicina Veterinária e Zootecnia da Universidade de São Paulo e foi aprovado em reunião de 10/07/2002.

(We certify that the Research "Pathogenicity factors of the Bacillus spp isolated in UHT milk" protocol number 173/2002, utilizing 100 mice and 10 rabbits, under the responsability of Prof.Dr. José Cezar Panetta, agree with Ethical Principles in Animal Research adopted by Bioethic Commision of the Faculty of Veterinary Medicine and Zootechny of University of São Paulo and was approved in 07/10/2002 meeting.)

São Paulo, 11 de julho de 2002

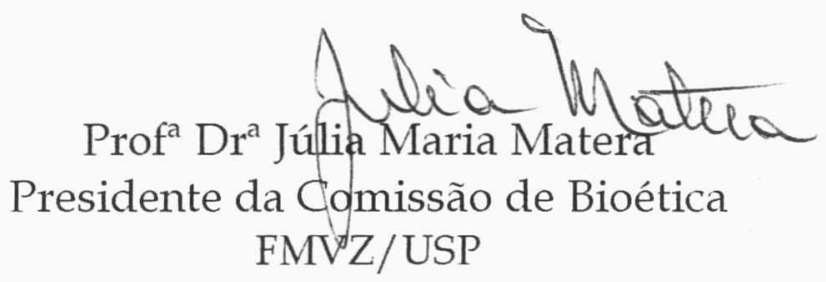

Av. Prof. Dr. Orlando Marques de Paiva, 87 - 05508-000 - Cid. Univ. "Armando de Salles Oliveira" Fones: (011) 3091-7671/3091-7676 Fax: (011) 3032-2224 


\section{FOLHA DE AVALIAÇÃO}

Nome: BARROS, Vera Regina Monteiro de

Título: Estudo de fatores de patogenicidade de Bacillus spp isolado em leite UHT

Tese apresentada ao Programa de PósGraduação em Epidemiologia Experimental Aplicada a Zoonoses da Faculdade de Medicina Veterinária e Zootecnia da Universidade de São Paulo para obtenção do título de Doutor em Medicina Veterinária

Data:

1

Banca Examinadora

Prof . Dr. Instituição

Assinatura Julgamento

Prof . Dr. Instituição

Assinatura Julgamento

Prof . Dr. Instituição

Assinatura Julgamento

Prof . Dr. Instituição

Assinatura Julgamento

Prof . Dr. Instituição

Assinatura Julgamento 


\section{DEDICATÓRIA}

Este trabalho foi elaborado com a finalidade de permitir a evolução profissional e científica pessoal, porém motivada pelo encontro com meus alunos de graduação da disciplina de Higiene e Inspeção de Produtos de Origem Animal, a quem dedico este documento. A eles não pretendi só ensinar, porém tive a ambição de deixar um exemplo de que devemos contribuir sempre de forma ética e responsável para a evolução do nosso país. 


\section{AGRADECIMENTOS}

Quando em minhas orações pedi ao SENHOR que me permitisse concluir este trabalho e que pudesse realmente contribuir de forma efetiva com a sociedade, recebi como SUA resposta a ajuda de pessoas especiais, que colaboraram com sua competência profissional e solidariedade, a quem agradeço :

Prof. Dr. José Cesar Panetta

Prof. Dr. Antônio José Piantino Ferreira

Profa. Dra. Claudete Serrano Astolfi Ferreira

Ms. Laura Villarreal

Dra. Miyoko Jakabi

Dra. Cristiane Ristori

Profa. Dra. Evelise Telles Ramos

Profa. Dra. Maria Regina Baccaro

Dra. Vera Lúcia Braga Isidoro

Orlando Bispo de Souza

Antonio da Costa Martins

Sandra Abelardo Sanches

Zenaide Maria Moraes

Alexandre Abelardo Sanches

Meus filhos

Iuri Monteiro de Barros

Bruna Monteiro de Barros

Giovana Monteiro de Barros 


\section{RESUMO}

BARROS, V. R. M. Estudo de fatores de patogenicidade de Bacillus spp isolado em leite UHT. [Pathogenicity factors of Bacillus spp isolated from UHT milk]. 2004. 117 f. Tese (Doutorado em Medicina Veterinária) - Faculdade de Medicina Veterinária e Zootecnia, Universidade São Paulo, São Paulo, 2004.

O leite produzido a ultra alta temperatura denominado oficiamente como UHT é o leite de maior aceitação no mercado consumidor brasileiro. Com a finalidade de ampliar o conhecimento sobre a segurança microbiológica do leite UHT, objetivouse estudar tanto os Bacillus spp, que vêm sendo relatados como contaminantes do leite UHT no Brasil, como os eventuais esporos sobreviventes ao processamento. A partir de 65 análises de leite UHT para a determinação de microrganismos mesófilos aeróbios estritos e facultativos viáveis, no leite UHT procedente das indústrias sob Inspeção Federal no estado de São Paulo, 7 apresentaram contagens acima de $100 \mathrm{UFC} / \mathrm{ml}$, indicando um percentual de $10,76 \%$ de provas fora dos padrões para essa determinação, no período de jul a nov de 2003. Entretanto por atuação dos controles de qualidade das indústrias partidas foram inutilizadas e o leite que foi ao consumo apresentou $7,69 \%$ de microrganismos mesofílicos aeróbios acima dos padrões, sendo que $6.15 \%$ destes microrganismos foram considerados como Bacillus sporothermodurans. Dos isolamentos das contagens de microrganismos mesófilos acima dos padrões, foram efetuados estudos de seis 
cepas de Bacillus spp do leite UHT das indústrias, além de três cepas isoladas do leite UHT alvo de reclamações de consumidores procedente do Instituto Adolfo Lutz da capital de São Paulo. O objetivo do presente projeto foi, após a identificação cultural, microscópica, bioquímica e genética de culturas do Bacillus spp, estudar a patogenicidade das amostras em diversos modelos experimentais como: Teste do camundongo neonatos, alça ligada de coelho, inoculação intraperitoneal em camundongo BALB C e culturas celulares (Vero, HEp2 e Fibroblastos de Embrião de Galinha). As 3 amostras isoladas de leite de reclamações dos consumidores do Instituto Adolfo Lutz de São Paulo foram tipificadas preliminarmente pela técnica de Espectroscopia Infra-Vermelho a Transformada Fourier (FT- IR) como Bacillus flexus, enquanto que as amostras isoladas do leite procedente de três indústrias de São Paulo apresentaram presença de B. flexus e B.oleronius e Bacillus sporothermodurans. Exemplares de B.flexus testados quanto a patogenicidade apresentaram efeito citopático nas culturas celulares Vero, HEP2 e Fibroblastos de Embrião de Galinha e morbidade em camundongo BALB C. O Bacillus sporothermodurans não apresentou patogenicidade a nenhum dos modelos biológicos citados.

Palavras-chave: Leite. Esporos bacterianos. Patogenia animal. Citotoxicinas. 


\section{ABSTRACT}

BARROS, V. R. M. Pathogenicity factors of Bacillus spp isolated from UHT milk. [Estudo de fatores de patogenicidade de Bacillus spp isolado em leite UHT]. 2004. 117 f. Tese (Doutorado em Medicina Veterinária) - Faculdade de Medicina Veterinária e Zootecnia, Universidade São Paulo, São Paulo, 2004.

The milk produced at ultra high temperature, denominated $\mathrm{UHT}$, is the most popular milk in the Brazilian market. With the intention of increasing the knowledge of microbiologic safety in UHT milk, we concentrated our study on the Bacillus spp, described as the most important contaminants of UHT milk in Brazil , and on possible survivors of the processing procedures. From the 65 analysis of UHT milk collected to determine the presence of strict, aerobe, mesophile microorganisms and viable options, coming from industries under Federal Inspection in São Paulo state, 7 presented a microbial count higher than 100CFU/ml, indicating a percentage of $10.76 \%$ samples outside the standard for this determination, in the period between July and November 2003. However, due to the quality control in industries, batches were rendered useless and the milk that went for consumption presented $7.69 \%$ mesophile microorganisms above standard, being these organisms $6.15 \%$ was considered Bacillus sporothermodurans. 
From the isolation of mesophile Bacillus counts above average, 5 strains Bacillus spp species from UHT industries were studied, as well as 3 strains isolated from UHT milk denounced by consumers of São Paulo city's Adolfo Lutz Institute. The aim of the project, following cultural, microscopic, biochemical and genetic identification of the Bacillus spp, was to study pathogenicity in samples from several experimental models, such as: neonatal mice; rabbit ileum loops, intraperitoneal inoculation of BALB C mice and cell cultures: Vero, Hep2 and Chick Embryo Fibroblasts. The three isolated samples of milk denounced by São Paulo consumers were typified as Bacillus flexus by the Fourier Infrared Transformed Espectroscopy (IF-FR) technique, while isolated samples of milk from 3 industries in São Paulo, accused the presence of the B. flexus, B. oleronius and Bacillus sporothermodurans. Samples of the $B$. flexus tested in terms of pathogenicity presented a citopatic effect upon cell cultures Vero, HeP2 and Chick Embryo Fibroblasts and a morbidity in mice BalbC. The Bacillus Sporothermodurans did not present pathogenicity in any of the biological models mentioned.

Key words: Milk. Bacterial's spores. Pathogeny. Animal pathogenicity. Citotoxins. 


\section{LISTA DE ILUSTRAÇÕES}

Figura 1 - Foto da Cultura de células Vero - controle................................. 80

Figura 2 - Foto da Cultura de células Vero inoculada com sobrenadante estéril de

B. flexus - Efeito citotóxico, após 2 horas................................. 81

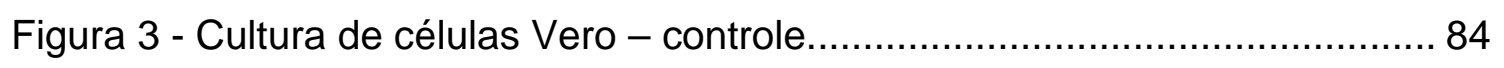

Figura 4 - Cultura de células Vero inoculada com sobrenadante estéril de Bacillus flexus - Efeito citotóxico, após 3 horas de inoculação.........................85 


\section{LISTA DE TABELAS}

Tabela 1 - Características das amostras de leite UHT, de três diferentes marcas, analisadas pela Seção de Microbiologia do Instituto Adolfo Lutz, São Paulo, procedentes de reclamações de consumidores, 2002. 64

Tabela 2 - Contagens de microrganismos mesófilos aeróbios e características bioquímicas de cepas de Bacillus spp isoladas de amostras de leite UHT procedentes de reclamações de consumidores avaliadas pela Seção de Microbiologia do Instituto Adolfo Lutz, São Paulo, 2002 65

Tabela 3 - Resultados de contagens de microrganismos aeróbios mesofílicos viáveis nas indústrias produtoras de Leite UHT sob Serviço de Inspeção Federal no Estado de São Paulo, efetuadas no Laboratório de Microbiologia de Alimentos do Departamento de Medicina Veterinária Preventiva e Saúde Animal- Faculdade de Medicina Veterinária e Zootecnia da USP, 2003 68

Tabela 4 - Resultados de contagens de microrganismos mesofílicos aeróbios e características boquímicas de cepas de Bacillus spp isolados de leite UHT procedentes de indústrias sob Inspeção Federal no Estado de São Paulo, efetuadas no Laboratório de Microbiologia de Alimentos do Departamento de Medicina Veterinária Preventiva e Saúde Animal- Faculdade de Medicina Veterinária e Zootecnia da USP, 2003 72

Tabela 5 - Diagnóstico molecular de cepas Bacillus flexus isoladas de amostras de leite UHT por Espectroscopia Infra-vermelho Transformada Fourier (FT-IR), de 2003. 
Tabela 6 - Observação da morbidade em lotes compostos de 10 Camundongos BALB C, após inoculação de sobrenadante estéril de culturas de B. flexus (lotes 1, 2, 3) , e culturas de B.flexus e B. oleronius ( lotes 4,5 ) e B. sporothermodurans (lotes 8, 9, 10), isolados de leite UHT, 2003-2004.................76

Tabela 7 - Resultados dos testes exatos de Fisher entre os lotes de camundongos BALB C controle e com os lotes inoculados com filtrados estéreis de Bacillus spp. Observações efetuadas em 5 horas e 24 horas pós inoculação, 2003 .77

Tabela 8 - Observação da Letalidade em Lotes de 10 Camundongos neonatos após inoculação de sobrenadante estéril de cultura de B.flexus, isolado de amostras de leite UHT,

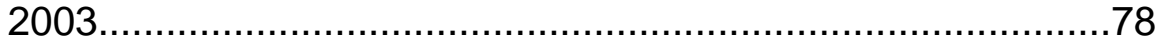

Tabela 9 - Culturas celulares, observações de efeitos citopáticos do sobrenadante estéril de Bacillus flexus em culturas celulares Vero, HEp 2 e Fibroblastos de Embrião de Galinha: Avaliação Morfológica após 3 horas de inoculação efetuada no Laboratório de Ornitopatologia do Departamento de Patologia VeterináriaFaculdade de Medicina Veterinária e Zootecnia da USP, 2003 
SUMÁRIO

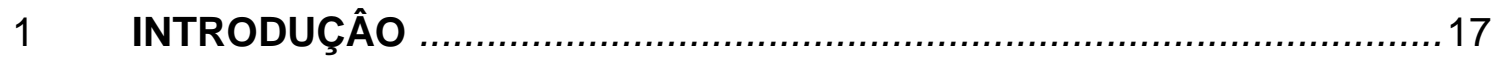

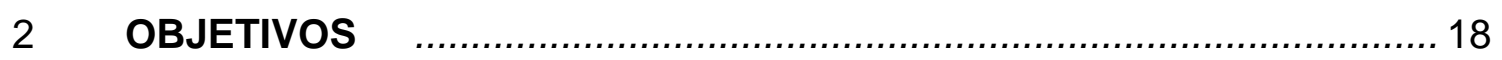

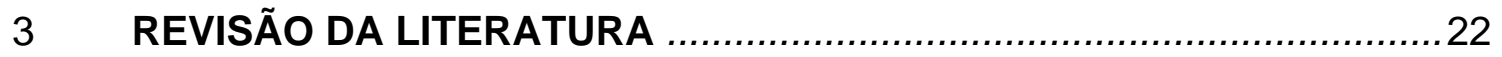

3.1 CLASSIFICAÇÃO EMERGENTE DO GÊNERO BACILLUS .................... 22

3.2 CARACTERÍSTICAS FENOTÍPICAS E DIAGNÓSTICO

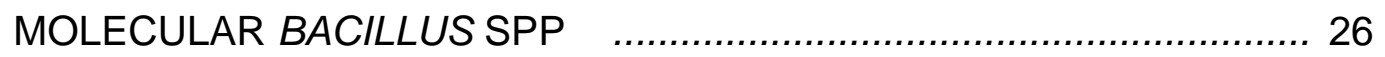

4 MÉTODOS INDUSTRIAIS DE PROCESSAMENTO A ULTRA

ALTA TEMPERATURA E SUA INFLUÊNCIA NA

PRESENÇA DE ESPOROS TERMO RESISTENTES............................... 31

4.1 BACILLUS SPP SOBREVIVENTES AO PROCESSO UHT ...................... 35

4.2 BACILLUS SPP CONTAMINANTES PÓS-PROCESSAMENTO UHT....... 40

4.3 ORIGEM DA CONTAMINAÇÃO DE BACILLUS SPP NO LEITE UHT.......42

5 FATORES DE PATOGENICIDADE DO BACILLUS SPP DETECTADO EM LEITE UHT

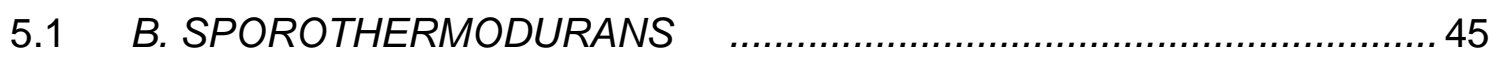

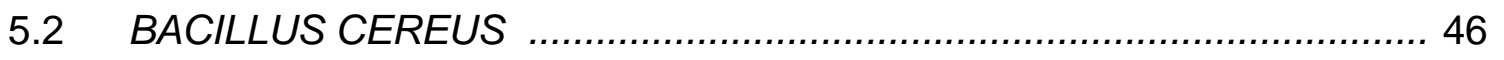

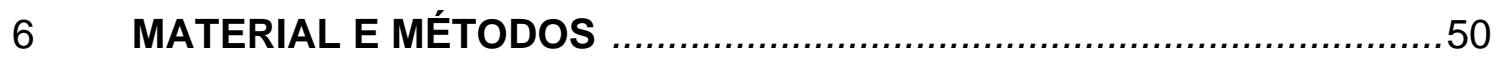

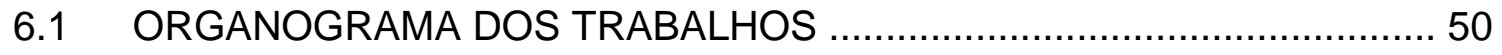


6.2 ISOLAMENTO, CONTAGEM E IDENTIFICAÇÃO

BIOQUÍMICA E GENÔMICA DO BACILLUS SPP

.51

6.2.1 DIAGNÓSTICO MOLECULAR - MÉTODO DE ESPECTROSCOPIA INFRAVERMELHO COM TRANSFORMADA À FOURIER (FT-IR) ....... 53

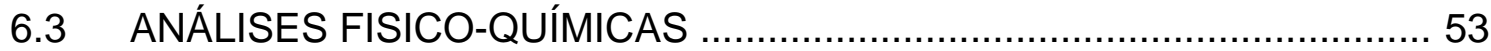

6.4 PREPARAÇÃO DO SOBRENADANTE DA CULTURA- BIOENSAIO ........55

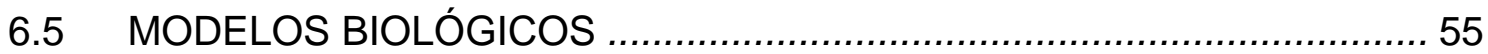

6.6 PROCEDIMENTO PARA INOCULAÇÃO NOS MODELOS BIOLÓGICOS57

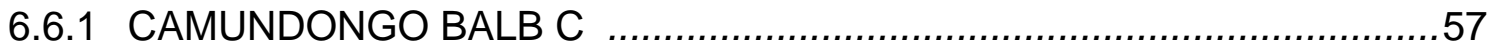

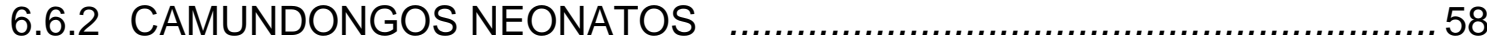

6.6.3 TESTE DE ALÇA LIGADA EM INTESTINO DE COELHO ...................... 57

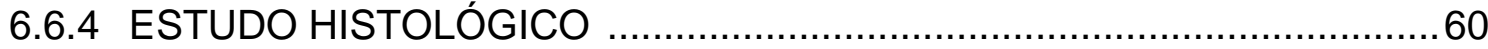

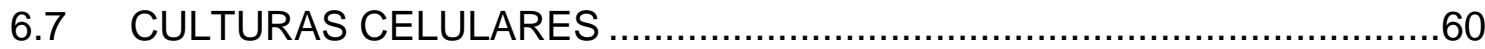

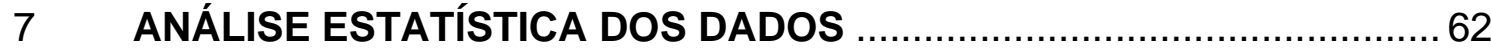

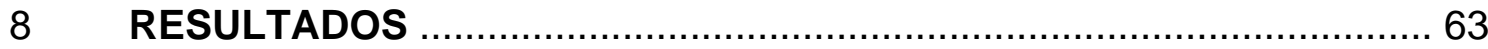

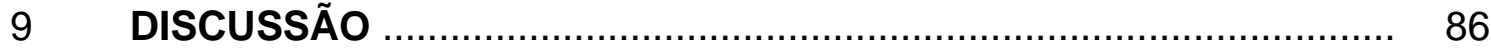

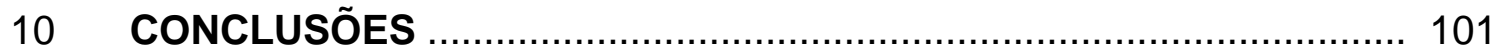

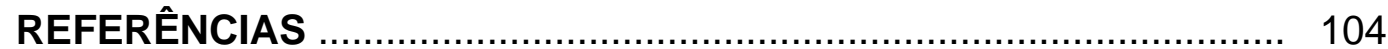

ANEXOS 


\section{INTRODUÇÃO}

O leite produzido a ultra alta temperatura denominado oficialmente como UHT/UAT é o leite de maior aceitação no mercado consumidor brasileiro.

Segundo Meireles (2000), a partir dos anos 90 o leite longa vida teve um impressionante crescimento, passando a dominar o mercado de leite fluído no Brasil. O autor atribui a mudança do varejo convencional, pequeno e próximo do consumidor, para o varejo grande e diversificado como um fator preponderante na mudança da preferência pelo leite UHT. Somando-se a estes aspectos, a facilidade de ser distribuído, estocado e vendido sem refrigeração, além da conveniência, segurança e qualidade, conduziram ao domínio deste produto no mercado do leite fluído no Brasil.

O consumo do produto cresceu significativamente nos últimos 10 anos em nosso país. Esta afirmativa é baseada no aumento da produção de leite UHT no Brasil, que em 1991 foi de 187 milhões de litros enquanto que no ano 2001 observa-se a produção de 5,3 bilhões de litros (ABVL, 2004). Através de pesquisas domiciliares somadas aos dados de comercialização das indústrias de laticínios, a Associação Brasileira de Leite Longa Vida (ABLV) observa que no ano 2000 o leite longa vida representou $68,8 \%$ do mercado formal de leite fluído no Brasil (MEIRELES ; ALVES, 2001). 
O consumidor adquire o leite UHT com a convicção de que é um alimento totalmente estéril e que não possui qualquer risco de causar enfermidades transmitidas por alimentos. Sob o aspecto da segurança, as normas oficiais brasileiras definem o produto como comercialmente estéril, quando determina que:

"Após 7 dias de incubação a $35^{\circ} \mathrm{C}-37^{\circ} \mathrm{C}$ de embalagens fechadas, não deve apresentar microrganismos patogênicos e causadores de alterações físicoquímicas e organolépticas do produto, em condições normais de armazenamento" (BRASIL, 2001). Ainda, o leite UHT é definido no Regulamento Técnico de Identidade e Qualidade (RTIQ), como leite homogeneizado que foi submetido, durante 2 a 4 segundos, a uma temperatura de $130^{\circ} \mathrm{C}$, mediante processo térmico de fluxo contínuo, imediatamente resfriado a uma temperatura inferior a $32^{\circ} \mathrm{C}$ e envasado sob condições assépticas e embalagens estéreis e hermeticamente fechadas (BRASIL,1997) . Portanto, a proposta legal para a produção do leite UHT é que deve ser um produto estéril comercialmente e desta forma as indústrias produtoras têm a possibilidade de comercializar o leite UHT com longo prazo de validade .

Quanto ao aspecto de segurança deste alimento, pode-se observar, consultando-se os dados do Serviço de Inspeção de Produtos de Origem Animal (SIF), órgão da Delegacia Federal de Agricultura de São Paulo, que são mínimas as reclamações dos consumidores em relação à qualidade do leite UHT.

Foram encaminhadas àquele Serviço, tanto pelo Centro de Vigilância Sanitária da Secretaria de Estado da Saúde de São Paulo, quanto pela Promotoria de 
Defesa do Consumidor de São Paulo (Procon), 34 reclamações de consumidores acerca da qualidade do leite UHT nos últimos 5 anos. Os resultados das avaliações feitas pelo SIF indicam que do total das reclamações, 31 foram devidas a defeitos como alterações de sabor, coloração amarronzada e coagulação, 1 causou somente vômitos pelo consumo de leite acidificado e 2 foram reclamações de outras alterações gastro-intestinais.

Entretanto, não houveram estudos epidemiológicos e tampouco microbiológicos das amostras tendo em vista as diversas dificuldades administrativas que impediram a recuperação das amostras originais dos consumidores ou ainda amostras dos lotes do produto alvo de reclamações.

Uma das causas deste baixo número de reclamações pode ser um real indicador de uma excelente qualidade do leite UHT produzido no Brasil, mas pode também ser pelo fato do consumidor encaminhar suas reclamações diretamente ao Serviço de Atendimento ao Consumidor da empresa responsável pela produção. Desta maneira, os órgãos de Fiscalização e Vigilância Sanitária do Brasil possuem escassas informações técnicas sobre o comportamento do produto no consumo (CVE,2004). 


\section{OBJETIVOS}

Com a finalidade de ampliar o conhecimento sobre a segurança microbiológica do leite UHT, objetivou-se estudar tanto os Bacillus spp, que vêm sendo relatados como mais importantes contaminantes do leite UHT no Brasil (REZENDE, 1998; SHOCHEN-ITURRINO; NADER FILHO; DIMENSTEIN; 1996; ZARCACHENCO, 1999), quanto aqueles Bacillus spp citados como sobreviventes ao processamento térmico na industrialização de leite UHT (ZARCACHENCO, 1999).

Portanto, para cumprir os objetivos propostos, foram efetuados os seguintes estudos:

- Avaliação microbiológica de amostras de leite UHT de todas as indústrias produtoras do estado de São Paulo. Conforme dados do Serviço de Inspeção Federal do Ministério da Agricultura e do Abastecimento de São Paulo são 13 o número de indústrias produtoras de leite UHT naquele Estado. Serão avaliadas, no mínimo, 5 amostras da produção de cada fábrica. As amostras serão analisadas microbiologicamente para observar o cumprimento da legislação vigente quanto à Contagem de microrganismos aeróbios mesófilos viáveis (BRASIL, 1997), com identificação bioquímica e molecular de eventuais Bacillus spp isolados . 
- Estudo dos fatores de patogenicidade de cepas de Bacillus spp isoladas em leite UHT em diversos modelos biológicos.

As amostras de Bacillus spp para este estudo serão aquelas obtidas tanto do leite procedente das indústrias do estado de São Paulo quanto das amostras de reclamações de consumidores ao Instituto Adolfo Lutz da capital de São Paulo. As amostras de Bacillus spp que serão alvos do estudo de patogenicidade, serão aquelas isoladas de leite UHT que apresentarem contagens de microrganismos mesófilos aeróbios acima dos padrões legais vigentes no Brasil de 100 UFC/ml (BRASIL, 1997). 


\section{REVISÃO DA LITERATURA}

\subsection{CLASSIFICAÇÃO EMERGENTE DO GÊNERO BACILLUS}

Bactérias que produzem endosporos resistentes ao calor são geralmente inclú́das na família Bacillacea. Como descrição do gênero, a produção de endosporos resistentes em presença de oxigênio permanece como característica do Bacillus. Os membros são Gram positivos (em culturas jovens), mas algumas vezes Gram variáveis ou mesmo Gram negativos, em forma de bastonetes, formadores de endosporos que podem ser aeróbios ou facultativos anaeróbios.

São freqüentemente catalase positivos e podem ser móveis por flagelos peritríquios.

A maioria das espécies é mesofílica, porém algumas podem ser psicrófilas e termófilas (LOGAN ; TURNBULL, 1999).

Tendo em vista que a formação do endosporo é uma característica desta bactéria, a morfologia do esporo teve peso significante na sua classificação e identificação. As primeiras classificações taxonômicas do gênero Bacillus foi muito confusa, existindo mais do que 150 espécies, geralmente descritas baseadas em única característica fisiológica ou ecológica. 
Em um estudo comparativo de mais de 1.000 cepas, Smith et al., (1952 apud PRIEST; GOODFELLOW; TODD, 1988) ${ }^{1}$, fundamentaram-se no formato, tamanho e localização do esporo na célula vegetativa como um meio de diferenciar grupos e desta maneira reduziram-se para 19 espécies de Bacillus. Esta divisão morfológica foi revisada e suplementada e algumas espécies não classificadas foram descritas. Embora os critérios utilizados para a classificação de Smith et al. (1952 apud PRIEST; GOODFELLOW; TODD, 1988) ${ }^{1}$ e Gordon et al. (1973 apud PRIEST; GOODFELLOW; TODD, 1988) ${ }^{2}$ tenham sofrido críticas e considerados insuficientes, são uma importante ferramenta e a base da classificação do genera Bacillus, apresentada no Bergey's Manual of Systematic Bacteriology (CLAUS; BERKELEY, 1986). Neste compêndio é apresentada a divisão de Gordon et al. (1973) que propõe a classificação do Gênero Bacillus em 3 grandes grupos, baseados no formato do endosporo e distensão do esporângio. Nesta classificação agrupam-se Bacillus spp no Grupo I, os que possuem endosporos elipsoidais e que não distendem o esporângio, no Grupo II com esporos elipsoidais que distendem o esporângio e, no Grupo III, esporos esféricos que distendem o esporângio.

1-SMITH, N. R.; GORDON, R. E.; CLARK, F. E. Aerobic mesophilic sporoforming bacteria United States Departament of Agriculture Monograph $n^{\circ}$ 16. Whash ington, DC: USDA. 1952. 2-GORDON, R. E.; HAYNES, W.C.; PANG,C.H-N. The Genus Bacillus (Agricultural Handbook $n^{\circ}$ 427). United States Departament of Agriculture. Whashington, DC. 1973. 
Ainda é apresentado no Bergey's Manual of Systematic Bacteriolog (SNEATH et al., 1999), estudo de Kaneda (1977) que em 19 espécies de Bacillus spp relacionando a composição predominante de ácidos graxos, divide o gênero em 6 grupos:

Grupo A: B. alvei, B. brevis, B.circulans, B. licheniformis, B. macerans, B. megaterium, B. pumilis, B. subtilis.

Grupo B: B. polimixa, B. larvae, B. lentimorbus, B. popilliae.

Grupo C: B.sthearothermophilus, B. caldolyticus, B. caldotenax.

Grupo D: B. acidocaldarius.

Grupo E: B. anthracis, B. cereus. B. thuringiensis.

Grupo F: B. globisporus, B. insolitus.

Os estudos taxonômicos das espécies não vêm determinando claras características morfológicas relativas ao esporângio ou na utilização dos carboidratos. Somada a estas dificuldades observam-se, através de estudos genômicos, que as características fenotípicas rotineiras utilizadas na distinção das espécies passaram a ter muito pouco valor (CHRISTIANSSON , TE GIFFEL, 2000).

A inadequação da classificação do gênero Bacillus foi enfatizada pelos estudos moleculares e observou-se com base na composição cromossomial do DNA um indicativo de diversidade genética (PRIEST et al., 1988) inclusive sugerindo classificação em diversos gêneros.

O gênero Bacillus, com base nas análises de rRNA pela seqüência parcial de oligonucleotídeo, tem indicado uma relação entre o genera Bacillus, Planococcus, Sporosarcina, Staphylococcus e Termoacthinomyces 
(STACKEBRANDT, et al., 198733; STACKEBRANDT, WOESE, $1981^{4}$ apud PRIEST et al., 1988).

Estudos taxométricos usando uma ampla escala de características têm mostrado ser uma efetiva ferramenta para revisão taxonômica dos grandes grupos desta bactéria. O primeiro alvo desta investigação foi estabelecer relações entre os gêneros e entre espécies representativas para muitas propriedades, usando procedimentos taxonômicos numéricos.

Recentes estudos agruparam o gênero Bacillus, conforme características comuns observadas em 368 cepas de Bacillus spp, estudando-se similaridade para 118 características, que foram agrupadas (LOGAN ; BERKELEY, 1981 apud PRIEST et al., 1988) 5 .

3-STACKEBRANDT, E.; LUDWIG,W.; WEIZENEGGER, DORN,S.; MACGILL,T.J.; FOX,G.E.; WOESE,C.R.; SCHUBERT,W.; SCHLEIFFER, K.M. Comparative 16s rRNA oligonucleotide analyses and murein types of round-spore-forming bacilli and non-spore-forming relatives.Journal of General Microbiolgy . n. 133. p. 2523-2529. 1987.

4-STACKEBRANDT, E.; WOESE, C.R. The evolution of prokaryotes.In_ Molecular and Cellular Aspects of Microbial Evolution. Ed. Carlile, Collins and Moseley. London. Academic Pres.

p.1-31. 1981.

5-LOGAN, N; BERKELEY, R.C.W. (Ed) Classification and Identifications of genus Bacillus using API test._In the aerobic espor-form bacteria; Classification and Identification 1981p $106-140$. 
A seguir são citados, dentre os representantes dos grupos, espécies comuns em todas as referidas publicações, tais como:

Agrupamento A: B. alvei; B. circulans; B. macerans; Agrupamento B: B. cereus; B. amyloliquefaciens; B. subtilis, B. pumilis; B. licheniformis; B. megaterium, B. flexus (revis B. fusiforme ). Agrupamento C: B. firmus; Agrupamento D: B. neurolyticus; B. brevis; B. sphaericus; Agrupamento E: B. lentus. Agrupamento F: B.coagulans; B. stearothermophilus.

Bacillus é considerado um gênero grande, muitas das espécies agrupam-se conforme características distintas no seqüenciamento rRNA, como os grupos pertencentes Bacillus subtilis, Bacillus cereus e Bacillus sphaericus. Entretanto, espécies intermediárias podem dificultar uma clara distinção fenotípica dos grupos e observa-se que constantemente novas espécies de aeróbios formadores de esporos estão sendo descritas. (LOGAN; TURNBULL, 1999).

\subsection{CARACTERÍSTICAS FENOTÍPICAS E DIAGNÓSTICO MOLECULAR BACILLUS SPP}

Sob o ponto de vista genético, o gênero Bacillus apresenta heterogenicidade, existindo membros com $\mathrm{C}+\mathrm{G}$ do DNA de 33 a $66 \mathrm{~mol} \%$. 
Devido à alta variabilidade fenotípica das espécies, os clássicos métodos morfológicos não vêm alcançando sucesso. Estudos numéricos aliados a cálculos de coeficientes de similaridade, ilustrados em dendrogramas, são um importante instrumento para a base da classificação de Bacillus spp particularmente quando aliados a métodos moleculares.

Portanto, uma classificação correta é um pré-requisito para a elaboração de teste de identificação de microrganismos, especialmente de Bacillus spp. Provas como Aglutinação Antigênica ou provas genéticas como Hibridação ou Reação em Cadeia da Polimerase (PCR) são importantes ferramentas no diagnóstico das espécies deste gênero.

A prova de PCR é um método comum para se obter grandes quantidades, por amplificação de um fragmento específico de DNA, e é um teste simples para identificação do Bacillus spp (CHRISTIANSSON ; TE GIFFEL, 2000) .

Os métodos de hibridação e PCR dependem da desnaturação e subseqüente separação das fitas duplas da hélice do DNA. Ambos os métodos dependem do papel complementar do par de bases. Isto é: adenina liga-se à tiamina, citosina à guanina.

A Hibridação é um processo no qual o DNA teste une-se a uma região complementar do DNA em fita simples ou RNA. O DNA teste é usualmente composto de 20-2000 nucleotídeos da seqüência do DNA que é único para um determinado grupo de microrganismo. Esta prova pode identificar genes específicos, seqüências de regiões rRNA ou DNA que, ainda que não possuam funções conhecidas, são comuns a determinados grupos bacterianos. O DNA teste pode ser preparado sintética ou biologicamente. Neste método pode ser 
usado um elemento radioativo como marcador. A prova da PCR é atualmente uma importante ferramenta para diagnóstico em microbiologia dos alimentos, Nesta prova é utilizada a enzima DNA polimerase para copiar exponencialmente uma seqüência específica a partir de um DNA-alvo. São necessários moldes de oligonucleotídeos para serem os iniciadores do processo. A partir dos oligonucleotídeos iniciadores do processo, a DNA-polimerase sintetiza a cadeia nascente de DNA, inserindo nucleotídeos correspondentes na ordem correta da seqüência do DNA alvo. Após este procedimento, a eletroforese em gel é utilizada para detectar o produto amplificado e desta forma proceder ao diagnóstico da espécie bacteriana (ENTIS, 2001).

Os métodos de tipagem celular são baseados nas características físicas de moléculas (ácidos graxos, proteínas, carboidratos, ácidos nucleicos) produzidas pelas bactérias. Em relação à identificação do gênero Bacillus utilizam-se diversos métodos (CRISTHIANSSON; TE GIFFEL, 2000).

Herman et al. (2000) destacam como mais utilizados para identificar especificamente cepas isoladas de Bacillus sporothermodurans em leite UHT a análise da seqüência do gen 16s rRNA, que, por apresentar alta variabilidade, o seu estudo possibilita a identificação do B. sporothermodurans. A utilização da PCR também é muito útil para identificação de espécies bacterianas nas quais há dificuldade de fazê-lo através do fenótipo, como é o caso de Bacillus sporothermodurans., isto é positivamente favorável tendo em vista que a prova pode ser utilizada sem necessidade de purificação da cultura. Este é um fator decisivo tendo em vista a dificuldade de purificação deste organismo pela existência da microbiota contaminante do leite. Identificação pelas técnicas 
moleculares mais abrangentes como a Análise da Amplificação do Polimorfismo do DNA (RAP) e Seqüência Repetitiva de Primers por PCR (REP-PCR) são utilizadas uma vez que o $B$. sporothermodurans é homogêneo a partir de métodos de tipificação molecular e espectofotometria de massa (KLIJN et al., 1997; PETTERSON et al., 1996). RAPD é baseado na amplificação da PCR diretamente por primers de seqüência arbitrária. Enquanto os tipos REP-PCR são baseados na sequência do palíndromo extragênico repetitivo.

Estes métodos podem ser utilizados para diagnosticar cepas isoladas do bacilo em leite UHT estéril ou não estéril.

Outros métodos estão sendo utilizados para obtenção de um diagnóstico molecular mais preciso, dentre eles o Método de Espectroscopia Infra-Vermelho à Transformada Fourier (FT-IR). O projeto de articulação para utilização desta tecnologia iniciou-se entre 1986 e 1989 para desenvolver técnicas eficientes de análise de bactérias e foi desenvolvido com o apoio do Ministério da Tecnologia e Pesquisa e Ministério da Saúde da Alemanha.

Trata-se de técnica física que produz um molde digital da bactéria, plenamente reprodutível e típico para diferentes microrganismos; é altamente específica e fornece um significativo número de informações quantitativas e qualitativas sobre uma determinada amostra (NAUMAN; HELM ; LABICHISKI,1991).

O espectro infra-vermelho produz uma impressão digital única da bactéria que possibilita o diagnóstico de espécies desconhecidas utilizando-se dados espectrais de bancos de estoque de bactérias. Os dados contêm os caracteres vibracionais de todos os constituintes celulares, como DNA/RNA, proteína, membranas e componentes das paredes celulares. Amostras de culturas 
celulares são retiradas do ágar e após diluição com água destilada são colocadas em prato ótico de Zinco - Selênio e a seguir secam em vácuo moderado (2,5 a 7,5 Kpa). A amostra é transferida para um filme transparente para absorção e transmissão do medidor infra-vermelho à transformada Fourier. A leitura é feita por bandas de absorbância de todos os constituintes das células. (HELM et al., 1991).

Em relação ao grupo $B$. cereus, no que se refere à diferenciação de suas espécies, somente poucas propriedades taxonômicas podem ser utilizadas para diferenciá-las. Dentre estas propriedades destacam-se a patogenicidade aos insetos e a toxina cristalina intracelular do $B$. thuringiensis, crescimento rizóide e ausência de motilidade do $B$. mycoides, ausência de hemólise e susceptibilidade ao fago gama e penicilina do $B$. anthracis.

Os estudos moleculares apontam para a possibilidade de serem as espécies deste grupo variantes ou sub-espécies de $B$. cereus. Dentre estes estudos, as análises do DNA e Eletroforese Enzimática Multilicus indicam que $0 \quad B$. thuringiensis e o $B$. cereus são indistingíveis quanto a este aspecto. Análises das seqüências do $16 S$ e $23 S$ indicam uma relação fechada entre os membros do grupo.

Recentemente foram desenvolvidas técnicas de identificação do DNA, baseadas nas estruturas $16 \mathrm{~S}$ do $\mathrm{rRNA}$, sendo utilizada a variação da região $\mathrm{V} 1$, desta forma pode-se distinguir as diferentes espécies do Grupo B. cereus (CRISTHIANSSON; TE GIFFEL, 2000). 


\section{MÉTOdOS INDUSTRIAIS DE PROCESSAMENTO A ULTRA ALTA TEMPERATURA E SUA INFLUÊNCIA NA PRESENÇA DE ESPOROS TERMO RESISTENTES}

O processo UHT é uma técnica para a preservação de alimentos líquidos através da sua exposição ao calor intenso por um rápido período de tempo. Este tratamento destrói os microrganismos do produto. Isto só se aplica se o produto permanecer em condições assépticas, por isso é necessário evitar a recontaminação utilizando-se embalagem em materiais assépticos imediatamente após o tratamento térmico.

Em uma planta de UHT moderna o leite é bombeado através de um sistema fechado. No trajeto, o leite será pré-aquecido, tratado com calor intenso, homogenizado, resfriado e envasado assepticamente. O leite, como outros produtos pouco ácidos, é tratado termicamente à temperatura de $130^{\circ} \mathrm{C}-150^{\circ} \mathrm{C}$ por 2-4 segundos (TETRA PAK,s.d.b) .

Existem 2 tipos de sistemas industriais de processamento UHT no mercado, um sistema de aquecimento direto e outro sistema de aquecimento indireto do leite. No sistema direto, o produto entra em contato diretamente com o meio de aquecimento, seguido de um resfriamento instantâneo em câmara de vácuo e 
eventualmente um resfriamento adicional indireto até atingir a temperatura de envase.

Os sistemas diretos são divididos em: sistema de injeção de vapor (vapor injetado no produto) e sistema de infusão de vapor (o produto é introduzido em uma câmara de vapor).

No sistema indireto, o calor é transferido de um meio de aquecimento para o produto através de uma parede divisória (paredes tubulares ou em placas). A base do sistema pode ser por trocadores de calor a placa; trocadores de calor tubulares e trocador de calor com superfície raspada.

As fases operacionais básicas do processo UHT são comuns a todos os processos, sendo que o processo inicia-se com a fase de pré-esterelização, onde é utilizada água quente que circulará nos equipamentos na mesma temperatura que o produto vai ser submetido. O tempo mínimo de préesterilização é de 30 minutos. Ocorrerá resfriamento dos equipamentos dependendo das exigências da produção. As fases da produção variam conforme o processo. No processo direto, o leite vem do tanque de equilíbrio a aproximadamente $4^{\circ} \mathrm{C}$, segue para a seção de pré-aquecimento do trocador a placas, onde será aquecido em $75^{\circ} \mathrm{C}$ a $85^{\circ} \mathrm{C}$ (HINRICHS; KESSLER, 1995), a pressão é elevada a 4 bar e o produto é direcionado para a válvula de injeção de vapor. O vapor é injetado no produto e a temperatura do leite se eleva instantaneamente de $138^{\circ} \mathrm{C}$ para $143^{\circ} \mathrm{C}$ (a pressão de 4 bar evita que o produto ferva), sendo mantido no retardador tubular por 5 segundos. A seguir será resfriado rapidamente em câmara de expansão, mantida através de bomba, com vácuo parcial. O vácuo é controlado a fim de que a quantidade de vapor ejetado 
do produto seja equivalente à quantidade previamente injetada. A seguir o leite é resfriado a $20^{\circ} \mathrm{C}$ em aparelho de placa ou tubular e segue para o envase em máquina asséptica (TETRA PAK, s.d.b).

No caso do processo por infusão de vapor, o princípio básico é aquecer o produto passando-o através de um equipamento com vapor. O processo de uma maneira geral é similar ao por injeção direta de vapor.

No processo indireto o leite é bombeado do tanque de armazenamento para o tanque de equilíbrio e para a seção de regeneração do trocador de calor a placa. Nesta seção o produto é aquecido a $75^{\circ} \mathrm{C}$ pelo leite UHT já processado, que é concomitantemente resfriado em contracorrente. O produto pré-aquecido é então homogenizado em uma pressão de 180 a 200 bar. O produto préaquecido e homogeneizado continua em direção à seção de aquecimento do trocador a placas, onde é aquecido a temperaturas de $137^{\circ} \mathrm{C}$ a $138^{\circ} \mathrm{C}$ e passando por retardador tubular por 4 segundos. O meio de aquecimento é a água quente com a temperatura regulada pela injeção de vapor.

Finalmente ocorre o resfriamento regenerativo em duas etapas: primeiro contra a água fria do circuito de água quente e depois contra o produto frio que está entrando. O produto frio que sai do regenerador vai diretamente para o envase asséptico.

O ciclo de limpeza CIP (cleaned in place) leva 70 a 90 minutos e é executado logo após a produção.

O efeito letal nos microrganismos pode ser expresso matematicamente como uma função logarítmica na qual avalia-se a eficácia do processo, qual seja: $\mathrm{K} . \mathrm{t}=$ $\log \mathrm{N} / \mathrm{Nt}$, onde $\mathrm{N}$ será o número de esporos originalmente presentes e Nt o 
número de esporos presentes após o tratamento por determinada temperatura em um tempo de tratamento $(\mathrm{t})$ e $\mathrm{K}$ constante do processo (TETRA PAK - s.d.a). Portanto, a eficácia do processo será definida pelo número de reduções decimais na contagem dos esporos bacterianos, alcançado pelo processo de ultra alta temperatura e dependerá não somente do binômio tempo/temperatura como da carga inicial de esporos na matéria-prima.

As diferenças de temperaturas utilizadas nos processo UHT direto e indireto podem ser um fator determinante para a sobrevivência de esporos termo resistentes. Esta afirmação baseia-se em experimentos que concluem que os esporos são termo resistentes às temperaturas de processamento UHT, podendo ser destruídos à temperatura de $140^{\circ} \mathrm{C}$ por 3,4 a 7,5 segundos (KLIJN et al, 2000).

Os microrganismos mais importantes que apresentam esporos termo resistentes são os Gêneros Bacillus e Clostridium spp que são freqüentemente relatados como contaminantes do leite cru e associados às práticas deficientes na fazenda, como por exemplo alimentação do gado com silagem de baixa qualidade (FIL, 1994).

As espécies de Bacilus spp são aeróbias, Gram positivas e formadoras de esporos. Como os esporos são fáceis e amplamente dispersos na natureza e sobrevivem à pasteurização, eles são importantes contaminantes dos alimentos. Algumas espécies de Bacillus spp, como B. cereus, B. subtilis e B. licheformis, têm sido associadas a doenças transmitidas por alimentos e espoliação a diversos produtos lácteos. Esporos altamente resistentes ao calor como o Bacilus sporothermodurans podem contribuir para reduzir a qualidade do leite e 
derivados lácteos porque são resistentes ao processo indireto de Ultra Alta Temperatura (UHT) sendo que a germinação dos esporos no produto pode levar

o leite a ser considerado inaceitável pelas legislações (VAEREWIJCK et al., 2001).

\subsection{BACILLUS SPP SOBREVIVENTES AO PROCESSO UHT}

Trabalhos de Mostert et al. ${ }^{1}(1979$ apud ZACARCHENCO, 1999), em análise de 167 amostras de leite UHT consideraram como resistentes ao processo UHT os Bacillus licheformis e Bacillus cereus, tendo em vista a sobrevivência dos esporos ao tratamento térmico de $110^{\circ} \mathrm{C}$ por 15 minutos.

Nos últimos anos, em nível internacional, o microrganismo Bacillus sporothermodurans (BSP) vem sendo isolado com maior freqüencia a partir de leite processado pelo sistema UHT (PRIEST; GOODFELOW; TODD,1988).

1-MOSTERT, J.F.; LUCK, H.; HURMAN, R.A.isolation, identification e practical properties of Bacillus species from UHT and sterelized milk.South Africa Journal of Dairy Technology.v.11, n.3, p 125-132, 1979. 
A bactéria mesofílica, que caracteriza-se por possuir esporo com alta resistência ao calor, foi detectada em leite UHT a partir de 1985. O seu endosporo resistente ao processo UHT, germinava e se multiplicava no leite estocado (KLIGN et al, 2000),.

Pettersson et al.(1996), da Universidade Heriot Watt de Edimburgo, propuseram o nome de Bacillus sporothermodurans para essa bactéria, recentemente descrita, que é filogeneticamente diferente de outras espécies de Bacillus, sendo considerada pertencente ao grupo do B. megaterium e ao gênero Bacillus (HAMMER, 2000a).

As primeiras observações da presença desse microrganismo em leite UHT, em níveis acima dos legais permitidos pela legislação, datam de 1985, na Itália e Áustria. Na Alemanha, em 1990, também foi confirmada sua presença, enquanto na Itália, em 1995, ocorre interdição de planta processadora de leite UHT, motivada pela presença do B. sporothermodurans (HAMMER; SUHREN ; HEECHEN ,1995).

Conforme relatado no trabalho de Pettersson et al. (1996), as bactérias do grupo produtoras de esporos altamente resistentes ao calor, denominanas HHRS, podem se multiplicar no leite até atingir uma população máxima de $10^{5} \mathrm{UFC} / \mathrm{ml}$ após estocagem a $30^{\circ} \mathrm{C}$ por 5 dias, não são patogênicas e não causam deterioração perceptível no produto. Como característica importante Pettersson et al. (1996) cita o fato do B. sporothermodurans não crescer em ágar padrão, porém desenvolver-se bem no meio infusão de cérebro e coração.

Estudos de presença de Bacillus spp foram efetuados por pesquisadores de diversos estados brasileiros, tal como a avaliação de 32 amostras de leite UHT 
no comércio da região de Ribeirão Preto, na qual concluiram os autores, dentre outras observações, que foi observada presença de Bacillus spp em 10,52\% das amostras (SCHOKEN-ITURRINO; NADER FILHO; DIMESTEIN, 1996 ). André et al. (1998) analisaram 50 amostras de leite UHT no consumo da cidade de Goiânia-GO, as quais apresentaram como resultado o isolamento, após choque térmico $\left(80^{\circ} \mathrm{C} / 10 \mathrm{~min}\right)$, de Bacillus spp em $10 \%$ das amostras (2\% do grupo cereus e $8 \%$ não pertencente a este grupo). Nenhuma amostra resultou positiva para gênero Clostridium, entretanto 10\% das amostras apresentaram presença de Sthapylococcus spp e Micrococcus spp.

Em São Paulo, efetuou-se um pioneiro trabalho sobre a presença do $B$. sporothermopdurans no leite UHT, por Zacarchenco (1999), constatando 45\% das unidades de leite UHT estudadas, procedentes de Goiás, São Paulo e mais três estados da região Sul, apresentavam-se acima dos padrões vigentes em relação à contagem de bactérias mesofílicas.

Após estudos culturais, bioquímicos e análise do polimorfismo do DNA, o autor concluiu que se tratava do Bacillus sporothermodurans. Observa ainda o autor que as contagens variaram de $2,0 \times 10^{4} \mathrm{UFC} / \mathrm{ml}$ a $10^{5} \mathrm{UFC} / \mathrm{ml}$.

Estudo subseqüente avaliou amostras de leite UHT, provenientes de 8 diferentes marcas, comercializadas em Fortaleza, e observa-se a presença em 4 amostras de um Bacillus spp, termo resistente ao processo. Nesse estudo não foi tipificada a espécie detectada (PEREIRA; MARTINS ; ALBUQUERQUE, 2000). Recentemente, Ramos e Silva (2001), em avaliação da qualidade da produção de leite UHT na capital de São Paulo, após análise de 30 amostras de leite UHT coletada diretamente das indústrias produtoras e 20 amostras de leite UHT do 
consumo, observa que as amostras das indústrias encontravam-se dentro dos padrões sanitários legais em relação à Contagem de Microrganismos Aeróbios Estritos e Facultativos Viáveis, enquanto que 20\% das amostras do consumo encontravam-se acima do limite crítico oficial quando utilizou para a pesquisa meio de enriquecimento $\mathrm{BHI}$.

A presença de Bacillus sporothermodurans no leite UHT do Brasil vem sendo alvo de estudos e debates dos técnicos do setor, o que ensejou posicionamento da Associação Brasileira de Leite Longa Vida (ABLV, 1997). Esta organização, preocupada com a ocorrência do microrganismo no Brasil, tendo em vista que o Serviço de Inspeção Federal do Ministério da Agricultura e do Abastecimento havia detectado vários lotes em desacordo com os padrões microbiológicos do Regulamento Técnico de Qualidade e Identidade para esse produto, publicou documento entitulado "Bacillus sporothermodurans, uma proposta de solução", no qual, após várias observações técnicas a respeito do bacilo e seu diagnóstico laboratorial, tece as seguintes recomendações, particularmente no que se refere à liberação dos lotes de leite que apresentem Bacillus sporothermodurans com contagens acima das legalmente permitidas:

Em condições normais de produção (ausência de falhas operacionais), o Bacillus sporothermodurans é o único microorganismo mesófílo capaz de sobreviver ao tratamento térmico convencional do leite UHT; 
1. O microrganismo, de acordo com a literatura disponível, não é patogênico;

2. Não causa alteração físico-química ou sensorial no leite;

3. A metodologia analítica proposta nestas regras permite a diferenciação de $B$. sporothermodurans de outros Bacillus mesofílicos, inclusive Bacillus cereus, este sim potencialmente patogênico;

4. As autoridades responsáveis pela fiscalização podem liberar para comercialização e consumo os lotes de leite longa vida que apresentem contagens de microrganismos mesófilos aeróbios superiores a $100 \mathrm{UFC} / \mathrm{ml}$, sem colocar em risco a saúde dos consumidores.

Apesar de existir, na época, consenso entre os pesquisadores, sobre a veracidade da observação da $A B V L$, houve sempre uma determinação, tanto das indústrias produtoras quanto da Empresa Tetra Pak, responsável pela implantação industrial do processo UHT no Brasil, que as plantas deveriam ser equipadas com o processo direto de ultra pasteurização, com a finalidade de destruição dos esporos e desta forma produzir leite com padrões que atendessem integralmente a legislação brasileira. 


\subsection{BACILLUS SPP CONTAMINANTES PÓS-PROCESSAMENTO UHT}

Membros do gênero Bacillus, notadamente o $B$. badius, $B$. cereus, $B$. liqueniformis, B. polimixa, B.subtilis e B. stearothermophilus podem eventualmente contaminar o leite UHT após processo durante a operação de envase (PETTERSSON et al., 1996).

Poucos trabalhos foram publicados em relação à prevalência de Bacillus spp em leite UHT, Mostert et al. ${ }^{1}$ (1979 apud ZACARCHENCO, 1999) analisaram 167 amostras de leite UHT e isolaram 16 espécies do gênero Bacillus. Consideram os autores como contaminantes pós-processamento, 14 espécies, dentre elas Bacillus pumilis, Bacillus coagulans, Bacillus subtilis, Bacillus polymyixa, Bacillus megaterium, Bacillus circulans, Bacillus alvei e Bacillus stearothermophilus.

Huch e Kim (1983) isolaram do leite UHT Bacillus circulans, Bacillus megaterium, Bacillus subtilis, Bacillus licheformis e Bacillus sphaericum. Estes apontaram como causas da quebra da esterilidade do produto falhas no tratamento térmico e na etapa de envase.

1-MOSTERT, J.F.; LUCK, H.; HURMAN, R.A.isolation, identification e practical properties of Bacillus species from UHT and sterelized milk.South Africa Journal of Dairy Technology.v.11, n.3, p 125-132, 1979. 
Dentre o gênero, o Bacillus cereus é a mais importante espécie em relação à higiene dos alimentos e saúde pública. O B. cereus é um bastonete Gram positivo, aeróbio facultativo cujos esporos não deformam o esporângio. Essa e outras características, incluindo as características bioquímicas, são usadas para diferenciar e confirmar a sua presença nos alimentos. Entretanto estas características são comuns tanto ao $B$. cereus var mycoides, $B$. thuringiensis e B.anthracis.

A diferenciação desses organismos depende da utilização de características determinantes de cada espécie como a motilidade, a maioria do $B$. cereus é móvel ou na presença de cristais de toxina, característica do $B$. thuringiensis e ainda da atividade hemolítica, comum à maioria do grupo, porém não apresentada pelo B. anthracis e finalmente pelo crescimento rizóide, característico do B. cereus var mycoide (FORSYTHE, 2002).

Procedimentos para isolar e identificar e quantificar o B.cereus sempre envolvem técnicas de semeadura em placas. Ágar sangue tem sido usado para isolar o bacilo de surtos de enfermidades transmitidas por alimentos. Vários meios para semeadura em placa vêm sendo desenvolvidos utilizando-se características do microrganismos como produção da hemolisina, atividade da lecitinase, propriedades de fermentação e características morfológicas. A polimixina B é incorporada ao meio de cultura com a finalidade de inibir competidores, particularmente bactérias gram negativas. O manitol é utilizado para diferenciar a fermentação dos outros Bacillus spp (HANSEN; LESER; HENDRIKSEN, 2001; TE GIFFEL et al., 2000) 
No Brasil, poucos trabalhos foram elaborados com isolamento do $B$. cereus em leite UHT. Quanto a este aspecto, Rezende (1998), ao estudar 120 amostras de leite UHT integral, procedente de 4 marcas, colhidas do varejo da cidade de São José do Rio Preto no estado de São Paulo, obteve 4 das amostras (3,3\%), com média geométrica de contagens de $B$. cereus entre $>10^{1} \mathrm{UFC} / \mathrm{ml}$ e $<10^{2} \mathrm{UFC} / \mathrm{ml}$, entretanto nenhuma da cepas apresentou enterotoxicidade quando submetida à prova de alça ligada de coelho.

\subsection{ORIGEM DA CONTAMINAÇÃO DE BACILLUS SPP NO LEITE UHT}

A contaminação do leite por esporos pode ocorrer na fazenda ou na indústria processadora como resultados de possíveis contaminações pós-processamento, como deficiências durante a industrialização, o que é raro tendo em vista a autoregulação informatizada do processo UHT.

Os esporos contaminantes do leite na fazenda podem ser originários principalmente do úbere do animal contaminado pelo solo, dos utensílios, da ordenhadeira mecânica ou do próprio ambiente. Sujidades do úbere e tetos são principal fonte de contaminação de esporos no leite cru, sendo que o solo e a alimentação do gado também representam um papel importante como fonte primária de contaminação na fazenda produtora. Os esporos contaminantes do alimento sobrevivem no trato digestivo e passam para as fezes (CHRISTIANSSON; BERTILSSON; SVENSSON, 1998). 
A incidência de esporos tem sido objeto de vários estudos, dentre os quais destaca-se o estudo sobre os esporos contidos em silagem oferecida ao gado leiteiro na Bélgica. Foram isoladas aproximadamente 100 espécies de Bacilli na silagem, avaliadas pela amplificação do DNA e seqüência de rDNA 16s.

Dentre as espécies isoladas, conforme Vaerewijck et al. (2001), após tratamento a $80^{\circ} \mathrm{C}$ por 10 minutos, foram identificados:

B. subtilis (32 isolamentos), B. pumilis (25 isolamentos), B. clausii (8 isolamentos). Ainda, foram isolados esporos altamente resistentes ao calor, sendo que, após tratamento por 30 minutos a $100^{\circ} \mathrm{C}$, foram identificados $B$. subtilis (5 isolamentos), $B$. sporothermodurans (3 isolamentos), $B$. amyloliquefaciens (1 isolamento), B. oleronius (1 isolamento) e B. palius (1 isolamento). O B. cereus foi encontrado em todas as silagens analisadas.

A contaminação do leite UHT pelo B sporothermodurans vem sendo detectada desde 1985. Esta é uma contaminação que não se dá pós-processamento, mas sim devido à sobrevivência do esporo ao processamento (PRIEST; GOODFELOW; TODD, 1988).

Diferentes fontes do B.sporothermodurans devem ser consideradas sendo a primeira possibilidade a do leite cru ser contaminado na fazenda. Em 1995 esta bactéria foi detectada no leite proveniente de fazenda produtora (HAMMER, 1995). Em 1996 método baseado em PCR foi aplicado em 100 amostras de leite cru provenientes de 6 diferentes regiões geográficas (VAEREWIJCK², apud HERMAN et al., 2000), sendo que a presença desse microrganismo foi 
detectada em três amostras, procedentes da mesma região. Esta positividade não pode ser confirmada em amostras obtidas após um mês na mesma região. Os resultados sugerem uma incidência e ocorrência local baixas e esporádica contaminação de esporos de B. sporothermodurans no leite cru. A explicação para este fato pode ser pelo fato do isolamento do leite na fazenda ser problemático e só ser conseguido após aquecimento do leite, com eliminação da microbiota e utilizando-se a característica de extrema termo resistência da bactéria (HERMAN et al., 2000).

Somente em 2 de 120 amostras de silagem de milho, de capim e açúcar de rabanete foram detectados esporos de S. sporothermodurans. Até aquele momento, contaminação do leite cru na fazenda via alimento ou equipamentos de ordenha é o mais provável, porém não provado (HAMMER et al., 1995). Reprocessamento de lotes UHT contaminados ou produtos lácteos contaminados podem ser considerados uma segunda fonte de contaminação de esporos do B. sporothermodurans. A terceira possibilidade de contaminação pode ser o processamento com leite em pó contaminado. Hammer, Suhren e Heechen (1995) reportaram o isolamento do bacilo em leite em pó utilizado em país não europeu. 


\section{FATORES DE PATOGENICIDADE DO BACILLUS SPP DETECTADO EM LEITE UHT}

No presente estudo foram descritos estudos relativos aos fatores de patogenicidade dos principais Bacillus spp detectados em vários estudos no leite UHT produzido no Brasil (ANDRÉ et al.,1998; REZENDE, 1998; SCHOCKEN-ITURRINO; NADER FILHO; DIMESTEIN, 1996; ZACARCHENCO, 1999).

\subsection{B. SPOROTHERMODURANS}

Até o presente, existe um único estudo sobre a patogenicidade do $B$. sporothermodurans (HAMMER et al., 1995), no qual são apresentados resultados dos trabalhos de 3 equipes do Instituto de Higiene da Alemanha, que testaram um bacilo mesofílico, posteriormente designado como $B$. sporothermodurans resistente ao processamento UHT, frente a diversos modelos biológicos, utilizando animais e culturas celulares, descritos a seguir :

\section{$\underline{\text { Patogenicidade em camundongos }}$}

Em trabalho de Cuthbert ; Jackson ${ }^{1}$ apud Hammer (2000b).

1- CUTHBERT, J. A.; JAKSON, B. Inversk Research Institute, Scotland: personal comunication. 
Foram utilizadas duas cepas do Bacillus sporothermodurans e um pacote de leite contaminado em 6 grupos de camundongos (5 machos e 5 fêmeas, por grupo). Neste modelo, foram ministrados aos camundongos, via oral e intravenosa, soluções contendo as bactérias em estudo. Não houve mortalidade e tampouco sinais clínicos foram observados.

Citotoxidade em células de ovário de hamster chinês ( $\mathrm{CHO}$ ) e outras Conforme trabalhos de LEMBKE $^{2}$ foram testadas duas amostras de $B$. sporothermodurans em quatro linhagens celulares: CHO, NCTC, Giradi heart cells e WI-38. Observou-se perda da capacidade de fixar o vermelho neutro, assim como a perda do conteúdo de proteína total indicando dano celular, entretanto, o crescimento das células W-38 foi incrementado por fator desconhecido, não apresentado, na coloração histológica, evidência de dano celular.

\section{Citotoxicidade em céls Vero}

Foram testadas 16 amostras do B.sporothermodurans, isoladas em amostras de leite UHT contaminado, utilizando-se testes KIT dehidrogenase lactatato. 
O modelo de culturas celular foi aplicado em 101 amostras sendo que os resultados foram $100 \%$ negativos.

$\underline{\text { Ovos embrionados }}$

Não foi observada virulência nos ovos testados em relação ao peso dos embriões. Hammer (2000b) afirma a necessidade de maiores estudos sobre o Bacillus sporothermodurans.

Recentes estudos sobre o Bacillus sporothermodurans permitiram aos autores concluírem que até o presente não há evidência de que o microrganismo seja patogênico ou produza toxina relevante.

Entretanto, devido ao pequeno número de cepas testadas, estes resultados podem no entanto somente serem considerados como resultados preliminares (LEMBKE, comunicação pessoal apud HAMMER, 2000b)

No Brasil existem estudos sobre a presença da bactéria no leite UHT, como os citados no presente trabalho, porém nenhum estudo sobre sua patogenicidade foi efetuado.

\subsection{BACILLUS CEREUS}

Mossel e Moreno Garcia (1985) consideram o B. cereus genericamente, como um agente de periculosidade moderada e de difusão limitada, sendo necessário um grande número de células para causar enfermidade, na ordem de $10^{7}$ UFC/ml ou g para causar sintomas da doença. 
O B. cereus é comumente encontrado em baixos níveis de $10^{2} \mathrm{UFC} / \mathrm{ml}$, nos alimentos, o que é considerado aceitável. Quando o alimento não é submetido em tempo/temperatura adequados, os níveis elevam-se para $10^{7} \mathrm{UFC} / \mathrm{g}$ ou $\mathrm{ml}$, desta forma podendo o alimento causar intoxicações alimentares. B. cereus causa 2 tipos de intoxicações alimentares, uma do tipo diarreica e outra do tipo emética.

O B. cereus produz a síndrome diarreica durante sua multiplicação no intestino delgado humano enquanto que na síndrome emética as toxinas são préformadas no alimento. Muitas toxinas foram descritas, como a enterotoxina diarreica, fator emético, Hemolisina I, Hemolisina II, Fosfatase C. A toxina causadora da diarréia é uma proteína de alto peso molecular (38 Kda a 46 Kda) e é inativada pelo calor a $56^{\circ} \mathrm{C}$ por 30 minutos. A toxina do tipo emético é termo resistente $\left(126^{\circ} \mathrm{C} / 90 \mathrm{~min}\right)$ e é um peptídeo de baixo peso molecular (1,2 Kda) (FORSYTHE, 2002).

Os sintomas da síndrome diarreica são diarréia aquosa e dores abdominais que ocorrem após 8 a 24 horas do consumo do alimento contaminado, esta síndrome é semelhante à determinada pelo Clostridium perfringens.

Os sintomas da síndrome emética são caracterizados por náuseas e vômitos que ocorrem entre meia e 6 horas após a ingestão do alimento contaminado e assemelha-se à intoxicação estafilocócica (CDC, 2003).

Uma grande variedade de alimentos incluindo carnes, peixes, leite e vegetais pode causar a síndrome diarreica enquanto que a síndrome emética pode ser causada por arroz, queijos e produtos ricos em amido (JAY, 1981) . 
Esporos de B. cereus têm sido encontrados também em cereais, legumes, vegetais, pimenta e no leite pasteurizado e em pó. As síndromes podem ser determinadas por inadequada refrigeração e subseqüente reaquecimento do alimentos que foram anteriormente cozidos. A maioria dos envenenamentos por alimentos continuam sem notificação e quando há este procedimento, na maioria delas o agente não é identificado. Portanto é de grande importância o reconhecimento dos sinais clínicos e a utilização de laboratórios apropriados que permitam o reconhecimento do $B$. cereus como agente da enfermidade transmitida por alimentos (CDC, 2003).

O B.cereus é um importante microrganismo responsável pela diminuição da vida de prateleira do leite pasteurizado e de outros produtos lácteos. Está associado a defeitos de sabor, amargor do creme e coagulação doce, devidos à ação de lipases, fosfolipases e proteinases por ele secretadas. Apesar da ocorrência mundial da bactéria no leite, existem relatos da síndrome em derivados lácteos, porém não em leite pasteurizado ou leite UHT. Não está claro se a presença de B. cereus no leite pasteurizado pode ser considerado um perigo. Apesar de estudos estatísticos, baseados nas condições de estocagem do produto nas residências, indicarem a possibilidade de que $7 \%$ a $4 \%$ do leite pasteurizado apresentarem entre $10^{5}$ a $10^{6} \mathrm{UFC} / \mathrm{ml}$ de $B$. cereus, não existem entretanto relatos de infecção ou intoxicação por esta bactéria em adultos devido a este alimento. Isto pode ser devido à não notificação da doença, que apresenta características de transitoriedade ou pela não produção de toxinas pela bactéria no leite devido à deficiência de aminoácidos, glicose e oxigênio disponível (NOTERMANS ; TE GIFFEL, 2000). 
6 MATERIAL E MÉTODOS

6.1 ORGANOGRAMA DOS TRABALHOS

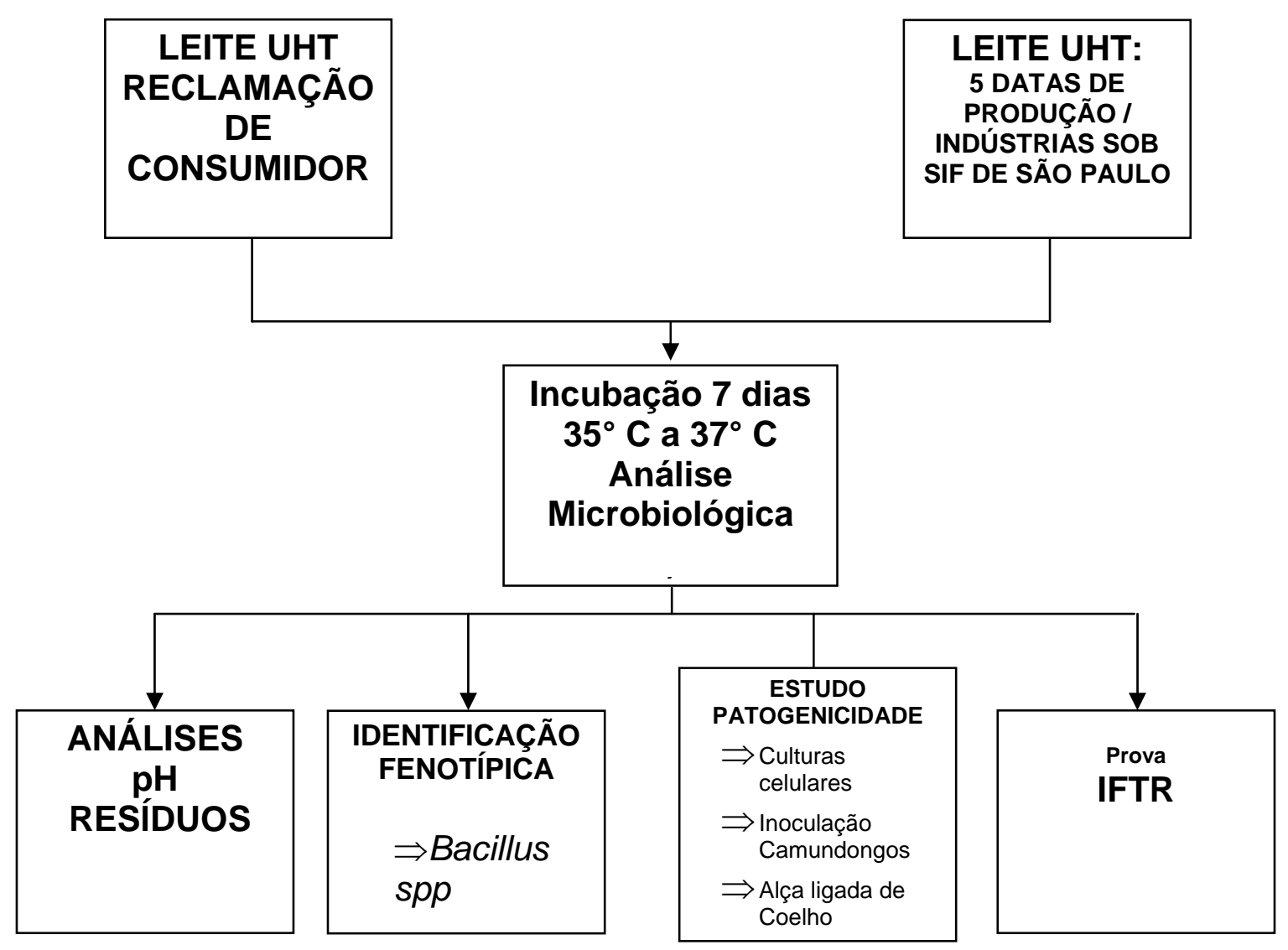




\subsection{ISOLAMENTO, CONTAGEM E IDENTIFICAÇÃO BIOQUÍMICA E GENÔMICA DO BACILLUS SPP}

Amostras de leite UHT procedentes de reclamações de consumidores tanto do Instituto Adolfo Lutz de São Paulo, quanto do Serviço de Inspeção Federal/SP, e amostras procedentes de todas as indústrias sob fiscalização do Serviço de Inspeção Federal de São Paulo que produzem leite UHT foram analisadas na Seções de Microbiologia Alimentar do Instituto Adolfo Lutz de São Paulo e Laboratórios de Higiene Alimentar e Patologia Veterinária da Faculdade de Medicina Veterinária da USP.

A amostragem do leite alvo de denúncias durante 2002 foi de 3 amostras nas quais a seção de Microbiologia de Alimentos o Instituto Adolfo Lutz isolou Bacillus spp.

Em relação à técnica de análise, conforme o Regulamento Técnico de Identidade e Qualidade do leite UHT (BRASIL, 1997), o leite foi incubado por 7 dias em $37^{\circ} \mathrm{C}$, em embalagem fechada e a seguir semeado, em aerobiose em ágar Infusão Cérebro-Coração (BHI) (BRASIL, 2003; ZARCACHENCO, 1999). Antes da retirada da alíquota, a embalagem do leite UHT será homogenizada, invertendo-as por 25 vezes e procedendo-se a assepsia com gaze estéril e álcool a $70^{\circ} \mathrm{GL}$. Para a abertura utilizou-se tesoura estéril e flambada (RAMOS E SILVA, 2001). 
O isolamento do Bacillus spp seguiu a metodologia proposta por Petterson et al., (1996) e Klinj et al.(1997).

O leite analisado no IAL/SP foi semeado em ágar nutritivo e ágar batata e havendo crescimento no ágar padrão foi semeado em ágar $\mathrm{BHI}$ sendo a seguir identificado.

O leite UHT coletado na Indústrias de São Paulo, foi semeado em diluições até $10^{2}$ em ágar BHI.

Foram feitas, no agar BHI, semeaduras em profundidade para a enumeração das colônias de microrganismos mesófilos aeróbios viáveis, em duplicata. Será considerada a diluição com colônias entre 25 a 250 UFC. Foi feita também semeadura em superfície para as diversas identificações morfológica, bioquímica, molecular e patogenicidade de cepas isoladas.

A semeadura em agar Polimixina Vermelho de Fenol foi efetuada somente em superfície.

As placas foram incubadas por 72 horas a $30^{\circ}{ }^{+}-1^{\circ} \mathrm{C}$ em aerobiose, com posterior contagem das colônias. Após observação das colônias, que se apresentavam uniformes e transparentes, foram isoladas 3 colônias e sendo a seguir efetuada identificação morfológica, coloração de Gram e semeadura em caldo BHI com vista ao isolamento de Bacillus spp.

As amostras que apresentarem contagens de microrganismps mesofílos aeróbios acima do padrão de $100 \mathrm{UFC} / \mathrm{ml}$, determinado pelo Regulamento Técnico de Identidade e Qualidade (BRASIL, 1997), ou que apresentarem microrganismos patogênicos ou causadores de alterações físicas, químicas ou organolépticas dos produtos, conforme determina a Agência Nacional da 
Vigilância Sanitária (BRASIL, 2001), terão os microrganismos submetidos a estudos de virulência.

A amostragem do leite alvo de denúncias durante 2002 constituiu-se de 3 amostras nas quais o Instituto Adolfo Lutz isolou Bacillus spp.

Em relação à amostragem das indústrias produtoras de leite UHT do estado de São Paulo, foram efetuados estudos em 5 amostras por unidade produtora.

Segundo dados do Serviço de Inspeção de Produtos de Origem Animal da Delegacia Federal de Agricultura de São Paulo, são 13 as unidades produtoras inspecionadas. O lote final será considerado o conjunto de unidades produtoras do Estado de São Paulo. Quanto ao processo industrial de aplicação da ultra alta temperatura, a maioria das indústrias utiliza o processo direto de injeção de vapor, enquanto a minoria utiliza processo indireto.

A ausência do microrganismo alvo em cinco amostras aleatoriamente escolhidas fornece $95 \%$ de confiança de que o lote esteja menos do que 50\% contaminado. Se 30 amostras forem avaliadas fornece informação, com confiança de 95\%, de que menos do que $10 \%$ do lote esteja contaminado (FORSHYTHE, 2002).

\subsubsection{DIAGNÓSTICO MOLECULAR - MÉTODO DE ESPECTROSCOPIA INFRAVERMELHO COM TRANSFORMADA À FOURIER (FT- IR)}


Este diagnóstico foi feito a partir dos isolamentos de Bacillus spp obtidos com a finalidade de um diagnóstico molecular considerado conclusivo em relação à espécie isolada (HELM et al., 1991; NAUMAN; HELM ; LABICHISKI,1991).

O equipamento FT-IR utilizado foi da maraca Brucker IFS 28B.

\subsection{ANÁLISES FÍSICO-QUÍMICAS}

As análises físico-químicas efetuadas no leite UHT foram provas de acidez utilizando-se o pH como seu indicador (BRASIL, 1997). Para a prova de $\mathrm{pH}$ foi utilizado o equipamento DMPH2 - marca Digimed. Para efetuar-se a medida eletrométrica de $\mathrm{pH}$, deve-se ajustar a curva de trabalho do equipamento através de soluções tampões de valores conhecidos. A calibração do equipamento foi feita sempre em 2 pontos. O primeiro ponto ajustado à $\mathrm{pH}$ 6,86 e o outro ponto em $\mathrm{pH}$ ácido de 4.0. As soluções utilizadas para calibração foram fornecidas pelo fabricante do equipamento. A sensibilidade do equipamento é de $80 \%$ a 100\%.

A faixa considerada normal para o leite é de 6,5 a 6,6 ( VEISSEYRE, 1972 ). Foi efetuada prova de presença de inibidores pelo método Delvotest R SP/SP. A prova apresenta sensibilidade, após incubação da amostra por $64^{\circ} \mathrm{C}$ durante 2 horas e 45 minutos, para penicilina $G$ de 2- 4 ng/ml; sulfadiacina de 25-100 ng/ml.*

* DSM Food Specialties Dayri Ingredients - www. dsm-foodspecialties.com 


\subsection{PREPARAÇÃO DO SOBRENADANTE DA CULTURA-BIOENSAIO}

O Bacillus spp, isolado e identificado microscopicamente e bioquimicamente, foi semeado em tubo com BHI líquido. Após o crescimento, o tubo que obtiver, através da comparação com a escala Mc Farland, crescimento equivalente a $10^{5}$ ufc/ml, será centrifugado em centrífuga refrigerada (Beckman J 2-21) a 10000 rpm/30 min, equivalente a $12000 \mathrm{~g}$. Este procedimento visa a separação das bactérias do sobrenadante que contêm as prováveis exotoxinas. 0 sobrenadante foi filtrado por filtros Millipore $n^{0}$ 0025. A seguir a amostra foi submetida a modelos biológicos, com vistas à observação da patogenicidade das bactérias em estudo (SPIRA ; GOEPFERT, 1975).

\subsection{MODELOS BIOLÓGICOS}

Após separação do sobrenadante de cada amostra, o mesmo foi inoculado nos seguintes modelos biológicos, com vistas à diagnóstico de presença de possível presença de exotoxina :

- Camundongos BALB C - 21 dias - injeção de 0,1 ml/animal intra peritoneal. 
- Alça ligada de coelho - injeção de $1 \mathrm{ml}$ do sobrenadante intra-alça intestinal de coelhos de aproximadamente $800 \mathrm{~g}$.

- Camundongos Neonatos - Administração de 0,1 ml sobrenadante da cultura por via intra-gástrica .

- Culturas celulares - Vero (rim de macaco verde africano), HEp2 (carcinoma de laringe humana) e Fibroblastos de Embrião de Galinha ( CUTHERT; JACKSON ${ }^{1}$ apud HAMMER, 2000b; FERREIRA, 1985) - Inoculação do sobrenadante da cultura de Bacillus spp. 


\subsection{PROCEDIMENTO PARA INOCULAÇÃO NOS MODELOS BIOLÓGICOS}

\subsubsection{CAMUNDONGO BALB C}

Os camundongos BALB C, com 21 dias, são animais monitorados procedentes do Biotério do Departamento de Patologia Veterinária da FMV USP. A inoculação foi efetuada intra-peritonialmente, tendo sido inoculado 0,1 $\mathrm{ml} /$ camundongo. Cada amostra foi inoculada em 1 lote composto de 10 animais. Com a finalidade de comparação do comportamento clínico dos camundongos, constituiu-se um Grupo Controle de 10 animais que foram inoculados somente com o meio de cultura (BHI).

O comportamento clínico dos animais (atividade motora, aspecto físico) foi observado de hora em hora, durante 8 horas pós-inoculação.

Animais com alterações de comportamento foram quantificados. A quantificação foi expressa através de fração numérica onde o numerador indica número de animais com alterações e o denominador, o número total de animais do lote.

Após 24 horas, observou-se novamente o comportamento clínico dos lotes sendo que após este período os animais foram sacrificados em câmara CO2 (CLOSE et al., 1977). 
Todos os animais inoculados e o grupo controle sacrificados foram necropsiados para coleta de fígados com vistas à exame histotológico.

\subsubsection{CAMUNDONGOS NEONATOS}

Os camundongos Neonatos (3 dias de nascimento), procedentes do Biotério do Departamento e Patologia Veterinária da Faculdade de Medicina Veterinária e Zootecnia da USP, são animais monitorados e foram submetidos à inoculação intra-gástrica com 0,1 $\mathrm{ml}$ do sobrenadante filtrado. Cada amostra foi inoculada em 1 lote composto de 10 animais sendo que o lote controle foi inoculado somente com o meio de cultura (BHI).

Após 24 horas de inoculação contabilizou-se o número de animais mortos de cada lote e a seguir os demais animais foram sacrificados em câmara de éter (CLOSE et al., 1977) e descartados.

\subsubsection{TESTE DE ALÇA LIGADA EM INTESTINO DE COELHO}

Para os testes de alça de coelho (SPIRA; GOEPFERT, 1972; MIKCHA, 1994), utilizaram-se coelhos albinos de $800 \mathrm{~g}$. Eles foram mantidos em dieta hídrica por 48 horas antes da realização dos testes. Os coelhos foram anestesiados com 
Nilperidrol (citrato de fentanola e doperidol) $0,3 \mathrm{ml} / \mathrm{Kg}$, utilizando-se a via intramuscular. Após a tricotomia e antissepsia da parede abdominal foi feita a incisão com exposição do intestino delgado. Após lavagem com solução salina foram feitas, em média, 6 ligaduras de $10 \mathrm{~cm}$ cada, intercaladas com alça de 5 $\mathrm{cm}$. As alças maiores receberam um inóculo de $1 \mathrm{ml}$ do sobrenadante da cultura de Bacillus spp, o procedimento foi efetuado em sala cirúrgica do Departamento de Patologia da Faculdade de Medicina Veterinária e Zootecnia da USP.

Os animais foram mantidos sedados com Telazol (zolazepan - tiletamina) - 0,2 $\mathrm{ml} / \mathrm{kg}$.

O volume de inóculo foi de $1 \mathrm{ml}$ de sobrenadante por alça ligada. Foram inoculadas alças controle positivo, Toxina $40 \mathrm{~T}$, em volume de 0,2 $\mathrm{ml}$ e alça controle negativo inoculada com $1 \mathrm{ml}$ de solução salina de 0,85\% .

A observação dos resultados será efetuada após 24 horas da inoculação, após o sacrifício do animal e observação de acúmulo de secreção nas alças intestinais. Foram considerados positivos os resultados de inoculação que apresentaram secreção considerável quando comparados ao teste controle. 


\subsubsection{ESTUDO HISTOLÓGICO}

Após observações dos resultados nos modelos biológicos, foram colhidas amostras de fígado dos camundongos BALB C e amostras das alças intestinais dos coelhos utilizados no experimento, para análises histopatológicas no Departamento de Patologia Veterinária da Faculdade de Medicina Veterinária e Zootecnia da USP.

\subsection{CULTURAS CELULARES}

Cada amostra do sobrenadante das culturas do Bacillus spp, obtida por centrifugação, foi avaliada em 3 tipos de culturas celulares (Vero, HEp2 e Fibroblastos de Embrião de Galinha). Foi utilizada cultura controle em todas as observações.

As culturas celulares Vero e HEp2 foram originalmente adquiridas no Setor de Cultura Celular do Instituto Adolfo Lutz, São Paulo. As culturas de Fibroblastos de Embrião de Galinha foram provenientes do Laboratório de Ornitopatologia do Depto. de Patologia Veterinária da Faculdade de Medicina Veterinária e Zootecnia da USP. 
As células foram cultivadas utilizando-se no meio de Eagle acrescido de Soro Fetal Bovino a 10\% e gentamamicina $10 \mathrm{mg} / \mathrm{ml}$. As células foram tripsinisadas e distribuídas no volume de 200 microlitros, por poço da microplaca. O tempo de crescimento das células foi de 24 horas, tempo necessário para a monocamada se formar completamente, sendo que as células foram mantidas por 24 horas a $37^{\circ} \mathrm{C}$ em estufa a $5 \%$ de $\mathrm{CO}_{2}$, antes da inoculação dos filtrados estéreis das amostras (FERREIRA, 1985).

Todas as amostras inoculadas nas diferentes linhagens de células foram diluidas até a diluição $10^{-4} \mathrm{em}$ : Meio de Eagle adicionado de Gentamicina $10 \mathrm{mg} / \mathrm{ml} \mathrm{e}$ $10 \mathrm{ml}$ soro fetal bovino (isento de Mycoplasma).

As leituras de possíveis efeitos citotóxicos nas culturas celulares foram feitas após 30 minutos após a inoculação, em microscópio invertido Leira.

Os efeitos citopáticos foram observados a partir de 3 horas da inoculação até 24 horas após inoculação. 


\section{ANÁLISE ESTATÍSTICA DOS DADOS}

O score obtido através da observação do comportamento clínico dos camundongos BALB C, dos diversos grupos inoculados, será avaliado em relação à porcentagem de morbidade do lote controle. As observações serão efetuadas em diferentes momentos após a inoculação, ou seja: após 5 horas e 24 horas. A partir destes resultados, será utilizado para a avaliação estatística o teste exato de Fisher (Agresti, 1990). Para a elaboração do teste utilizou-se os Softwares Excel 2000 e PSS 10.0.

Considera-se significativo ao teste resultados $<0,05$. 


\section{RESULTADOS}

Isolou-se Bacillus spp em 3 amostras de leite UHT, provenientes de reclamações de consumidores e encaminhadas ao Instituto Adolfo Lutz de São Paulo. As características das amostras e o tipo de reclamação do consumidor estão relatadas na tabela 1.

Os resultados das contagens de microrganismos mesófilos aeróbios viáveis, correspondentes às mesmas amostras, e que se apresentaram acima dos padrões do Regulamento Técnico de Identidade e Qualidade do leite UHT (BRASII, 1997) estão apresentados na tabela 2, assim como a caracterização bioquímica de cada cepa de Bacillus spp isolada. Os resultados das provas bioquímicas referentes às cepas isoladas das amostras números 1 e 2 podem ser considerados como características do $B$. sporothermodurans. Como características deste microrganismo podemos citar as provas de oxidase e esculina positivas e provas de nitrato e glicose negativas. Quanto aos resultados atinentes à cepa da amostra $n^{\circ} 3$ não foi conclusivo quanto à espécie, isto levando-se em conta que as provas bioquímicas utilizadas foram somente direcionadas à triagem das cepas, sendo que, para a determinação da espécie, prova complementar de FT-IR foi efetuada (informação verbal)*.

*Segundo JAKABI, M., da Seção de Microbiologia de Alimentos do Instituto Adolfo Lutz, São Paulo, 2003 
Tabela 1 - Características das amostras de leite UHT, de 3 diferentes marcas, analisadas pela Seção de Microbiologia do Instituto Adolfo Lutz, São Paulo, procedentes de reclamações de consumidores, 2002

\begin{tabular}{ccc}
\hline Número da amostra & $\begin{array}{c}\text { Data de produção da } \\
\text { amostra }\end{array}$ & $\begin{array}{c}\text { Tipo de reclamação do } \\
\text { consumidor }\end{array}$ \\
\hline 1 & $13 / 02 / 2002$ & $\begin{array}{c}3 \text { crianças com diarréia } \\
\text { forte odor azedo }\end{array}$ \\
2 & $13 / 04 / 2002$ & Sem reclamação objetiva \\
3 & $20 / 07 / 2002$ & Sem reclamação objetiva \\
& & \\
\hline
\end{tabular}


Tabela 2 - Contagens de microrganismos mesófilos aeróbios viáveis e características bioquímicas de cepas de Bacillus spp isoladas de amostras de leite UHT procedentes de reclamações de consumidores e analisadas pela Seção de Microbiologia do Instituto Adolfo Lutz, São Paulo, 2002

\begin{tabular}{ccccccccc}
\hline $\begin{array}{c}\text { Número } \\
\text { da } \\
\text { amostra }\end{array}$ & $\begin{array}{c}\text { Contagem de } \\
\text { bactérias } \\
\text { aeróbias } \\
\text { mesófilas (ufc/ml) }\end{array}$ & & Caracterização bioquímica das amostras & \\
\hline 1 & $2,6 \times 10^{3}$ & Pos & Pos & Neg & Neg & Neg & Pos \\
2 & $9,1 \times 10^{4}$ & Pos & Pos & Neg & Neg & Neg & Pos \\
3 & $1,1 \times 10^{5}$ & Neg & Pos & Neg & Pos & Neg & Pos \\
\hline
\end{tabular}


Paralelamente, foram analisadas, quanto à presença de microrganismos mesófilos aeróbios viáveis, 5 amostras do leite UHT de cada uma das indústrias prrocessadoras do Estado de São Paulo, sob jurisdição do Serviço de Inspeção Federal do Ministério da Agricultura, Pecuária e Abastecimento, num total de 65 amostras.

As análises foram efetuadas no Laboratório de Microbiologia de Alimentos do Departamento de Medicina Veterinária Preventiva e Saúde Animal da Faculdade de Medicina Veterinária da Universidade de São Paulo e os resultados obtidos encontram-se na tabela 3 .

Observou-se que em 7 amostras as contagens apresentaram-se acima de $3,010^{3} \mathrm{UFC} / \mathrm{ml}$

As produções relativas a duas destas amostras não foram direcionadas ao consumo, tendo em vista os problemas detectados em relação a estas elevadas contagens de microrganismos aeróbios mesófilos. Estas produções foram inutilizadas.

As demais 5 amostras, que apresentaram contagens acima dos padrões de microrganismos mesófilos aeróbios viáveis, em relação ao determinado pelo Regulamento Técnico de Identidade e Qualidade, foram para o mercado consumidor.

Em relação às outras 58 amostras, não foi observado crescimento de microrganismos mesófilos aeróbios nos meios de cultura utilizados e portanto apresentaram-se abaixo dos padrões para produção do Leite UHT (BRASIL, 1997). 
Portanto, de 65 amostras de leite UHT procedentes das indústrias sob Inspeção Federal analisadas quanto à presença de microrganismos aeróbios mesófilos viáveis, 7 apresentaram contagens acima do 100 ufc/ml indicando um percentual de $10,76 \%$ das amostras acima dos padrões da legislação federal (BRASIL, 1997) .

Entretanto, em relação ao leite UHT avaliado e direcionado ao consumo houve prevalência de 7,69\% em relação à não conformidade dos citados padrões.

Todas as amostras apresentaram negatividade para a prova de Delvotest $\mathrm{R}$, indicando ausência de resíduos de inibidores, tais como antibióticos, componentes de sulfa, desinfetantes e detergentes.

Todas as amostras, inclusive as partidas condenadas, apresentaram $\mathrm{pH}$ entre 6,5 e 6.7, considerados dentro da normalidade para o Leite UHT. 
Tabela 3 - Resultados de contagens de microrganismos mesófilos aeróbios viáveis nas indústrias produtoras de Leite UHT sob Serviço de Inspeção Federal no Estado de São Paulo, efetuadas no Laboratório de Microbiologia de Alimentos do Departamento de Medicina Veterinária Preventiva e Saúde Animal - Faculdade de Medicina Veterinária e Zootecnia - USP, 2003

\begin{tabular}{|c|c|c|c|}
\hline $\begin{array}{l}\text { Número da amostra por } \\
\text { indústria produtora }\end{array}$ & $\begin{array}{l}\text { Tipo de leite/data } \\
\text { fabricação }\end{array}$ & $\begin{array}{c}\text { Resultados } \\
\text { Contagem } \\
\text { Microrganismos } \\
\text { Mesóficos Aerobiose } \\
\text { (ufc/ ml) } \\
\text { Em ágar BHI }\end{array}$ & $\begin{array}{c}\mathrm{pH} \mathrm{da} \\
\text { amostra }\end{array}$ \\
\hline SIF A & Integral/ 0707 & Aus & 6,62 \\
\hline SIF A & Integral/ 0707 & $>2,5 \cdot 10^{2}$ & 6,60 \\
\hline SIF A & Integral/ 1711 & $>2,510^{2}$ & 6,50 \\
\hline SIF A & Integral/ 1711 & $>2,5 \cdot 10^{2}$ & 6,55 \\
\hline SIF A & Desnatado /17 11 & $>2,5 \cdot 10^{2}$ & 6,65 \\
\hline SIF B & Integral/ 0309 & Aus & 6,63 \\
\hline SIF B & Integral/ 0707 & Aus & 6,64 \\
\hline SIF B & Desnatado/ 1009 & Aus & 6,65 \\
\hline SIF B & Desnatado/ 0707 & 20 est & 6,63 \\
\hline SIF B & Integral/ 1009 & Aus & 6,63 \\
\hline SIF C & Desnatado 2807 & Aus & 6,60 \\
\hline SIF C & Desnatado 1308 & Aus & 6,60 \\
\hline SIF C & Integral/ 0611 & Aus & 6,68 \\
\hline SIF C & Integral/ 1911 & Aus & 6,66 \\
\hline SIF C & Desnatado 0212 & Aus & 6,68 \\
\hline SIF D & Integral/ 0507 & Aus & 6,70 \\
\hline
\end{tabular}




\begin{tabular}{|c|c|c|c|}
\hline $\begin{array}{l}\text { Número da amostra por } \\
\text { indústria produtora }\end{array}$ & $\begin{array}{l}\text { Tipo de leite/data } \\
\text { fabricação }\end{array}$ & $\begin{array}{c}\text { Resultados } \\
\text { Contagem } \\
\text { Microrganismos } \\
\text { Mesóficos Aerobiose } \\
\text { (ufc/ ml) } \\
\text { Em ágar BHI }\end{array}$ & $\begin{array}{l}\mathrm{pH} \mathrm{da} \\
\text { amostra }\end{array}$ \\
\hline SIF D & Desnatado 2809 & Aus & 6,70 \\
\hline SIF D & Integral/ 2307 & Aus & 6,71 \\
\hline SIF D & Integral/ 0408 & Aus & 6,71 \\
\hline SIIF D & Desnatado 0208 & Aus & 6,69 \\
\hline SIF E & Integral/ 2809 & Aus & 6,67 \\
\hline SIF E & Integral/ 2909 & Aus & 6,73 \\
\hline SIF E & Desnatado/ 2809 & Aus & 6,63 \\
\hline SIF E & Desnatado/ 2809 & Aus & 6,64 \\
\hline SIF E & Integral /01 10 & Aus & 6,64 \\
\hline SIF F & Desnatado/ 0210 & Aus & 6,64 \\
\hline SIF F & Desnatado/ 2909 & Aus & 6,60 \\
\hline SIF F & Integral/ 0608 & Aus & 6,61 \\
\hline SIF F & Desnatado/ 2909 & Aus & 6,60 \\
\hline SIF F & Desnatado/ 3009 & Aus & 6,62 \\
\hline SIF G & Integral/ 2108 & Aus & 6,62 \\
\hline SIF G & Integral/ 3009 & Aus & 6,76 \\
\hline SIF G & Desnatado/ 0110 & Aus & 6,73 \\
\hline SIF G & Integral/ 0110 & Aus & 6,60 \\
\hline
\end{tabular}




\begin{tabular}{|c|c|c|c|}
\hline $\begin{array}{l}\text { Número da amostra por } \\
\text { indústria produtora }\end{array}$ & $\begin{array}{l}\text { Tipo de leite/data } \\
\text { fabricação }\end{array}$ & $\begin{array}{c}\text { Resultados } \\
\text { Contagem } \\
\text { Microrganismos } \\
\text { Mesóficos Aerobiose } \\
\text { (ufc/ ml) } \\
\text { Em ágar BHI }\end{array}$ & $\begin{array}{l}\mathrm{pH} \mathrm{da} \\
\text { amostra }\end{array}$ \\
\hline SIF G & Integral/ 0410 & Aus & 6,65 \\
\hline SIF H & Desnatado/ 3009 & Aus & 6,67 \\
\hline SIF H & Desnatado/ 2909 & Aus & 6,68 \\
\hline SIF H & Integral/ 2909 & Aus & 6,54 \\
\hline SIF H & Integral/ 0608 & $>3,0.10^{3}$ & 6,70 \\
\hline SIF H & Desnatado/ 0508 & Aus & 6,75 \\
\hline SIF I & Desnatado/ 0110 & Aus & 6,73 \\
\hline SIF I & Integral/ 0110 & Aus & 6,59 \\
\hline SIF I & Desnatado / 2108 & Aus & 6,68 \\
\hline SIF I & Integral/ 3009 & Aus & 6,67 \\
\hline SIF I & Integral/ 1609 & Aus & 6,54 \\
\hline SIF J & Integral/ 2910 & $>3,010^{3}$ & 6.49 \\
\hline SIF J & Desnatado/ 2510 & Aus & 6,57 \\
\hline SIF J & Integral / 2410 & Aus & 6,68 \\
\hline SIF J & Desnatad / 2610 & Aus & 6,68 \\
\hline SIF J & Integral / 2910 & Aus & 6,69 \\
\hline SIF K & Desnatado/ 2310 & $>3,010^{3}$ & 6,70 \\
\hline SIF K & Desnatado / 1410 & Aus & 6,74 \\
\hline SIF K & Desnatado / 1410 & Aus & 6,72 \\
\hline
\end{tabular}




\begin{tabular}{|c|c|c|c|}
\hline $\begin{array}{l}\text { Número da amostra por } \\
\text { indústria produtora }\end{array}$ & $\begin{array}{l}\text { Tipo de leite/data } \\
\text { fabricação }\end{array}$ & $\begin{array}{c}\text { Resultados } \\
\text { Contagem } \\
\text { Microrganismos } \\
\text { Mesóficos Aerobiose } \\
\text { (ufc/ ml) } \\
\text { Em ágar BHI }\end{array}$ & $\begin{array}{l}\mathrm{pH} \mathrm{da} \\
\text { amostra }\end{array}$ \\
\hline SIF K & Integral/ 2410 & Aus & 6,69 \\
\hline SIF K & Integral / 2310 & Aus & 6,75 \\
\hline SIF L & Desnatado / 2307 & Aus & 6,79 \\
\hline SIF L & Integral / 2310 & Aus & 6,79 \\
\hline SIF L & Integral / 2910 & Aus & 6,84 \\
\hline SIF L & Integral / 2910 & Aus & 6,80 \\
\hline SIF L & Integral / 0811 & 48 & 6.63 \\
\hline SIF M & Integral/ 0811 & Aus & 6,70 \\
\hline SIF M & Integral/ 1011 & Aus & 6,71 \\
\hline SIF M & Integral/ 1111 & Aus & 6,73 \\
\hline SIF M & Integral/ / 1311 & Aus & 6,78 \\
\hline SIF M & Integral/ 1411 & Aus & 6,78 \\
\hline
\end{tabular}

Nota: Na primeira coluna desta tabela, cada letra refere-se à indústria produtora do leite UHT, sob Inspeção Federal. 
Tabela 4 - Resultados de contagens de microrganismos mesofílicos aeróbios características bioquímicas de cepas de Bacillus spp isoladas de leite UHT procedentes de indústrias sob Inspeção Federal no Estado de São Paulo, efetuadas no Laboratório de Microbiologia de Alimentos do Departamento de Medicina Veterinária Preventiva e Saúde Animal - Faculdade de Medicina Veterinária e Zootecnia USP, 2003

\begin{tabular}{|c|c|c|c|c|c|c|c|}
\hline \multirow{2}{*}{$\begin{array}{l}\text { Número } \\
\text { da } \\
\text { amostra }\end{array}$} & \multirow{2}{*}{$\begin{array}{c}\text { Contagem de } \\
\text { bactérias } \\
\text { mesófilas (ufc/ml) }\end{array}$} & \multicolumn{6}{|c|}{$\begin{array}{c}\text { Caracterização bioquímica } \\
\text { Bacillus spp isolados }\end{array}$} \\
\hline & & Oxidase & Esculina & VP & Nitrato & Glicose & Catalase \\
\hline 4 & $>2,510^{2}$ & $\mathrm{Neg}$ & $\mathrm{Neg}$ & $\mathrm{Neg}$ & $\mathrm{Neg}$ & $\mathrm{O} / \mathrm{F}$ & Pos \\
\hline 5 & $>2,5 \times 10^{2}$ & $\mathrm{Neg}$ & $\mathrm{Neg}$ & Neg & Pos & $\mathrm{O} / \mathrm{F}$ & Pos \\
\hline 6 & $>3,0 \times 10^{3}$ & $\mathrm{Neg}$ & $\mathrm{Neg}$ & Neg & Pos & $\mathrm{O} / \mathrm{F}$ & Pos \\
\hline 7 & $>3,0 \times 10^{3}$ & $\mathrm{Neg}$ & $\mathrm{Neg}$ & Neg & Pos & $\mathrm{O} / \mathrm{F}$ & Pos \\
\hline 8 & $>3,0 \times 10^{3}$ & $\begin{array}{c}\mathrm{Neg} / \\
\mathrm{Pos}\end{array}$ & $\mathrm{Neg}$ & Neg & $\mathrm{Neg}$ & $\mathrm{Neg}$ & Pos \\
\hline 9 & $>3,0 \times 10^{3}$ & $\begin{array}{c}\text { Neg/ } \\
\text { Pos }\end{array}$ & $\mathrm{Neg}$ & $\begin{array}{l}\text { Pos/ } \\
\text { Neg }\end{array}$ & Neg & $\mathrm{Neg}$ & Pos \\
\hline 10 & $>3,0 \times 10^{3}$ & $\begin{array}{l}\text { Neg/ } \\
\text { Pos }\end{array}$ & $\mathrm{Neg}$ & $\mathrm{Neg}$ & Neg & $\mathrm{Neg}$ & Pos \\
\hline 11 & $>3,0 \times 10^{3}$ & $\mathrm{Neg}$ & Pos Fraco & Neg & Neg & $\mathrm{Neg}$ & Pos \\
\hline
\end{tabular}


Conforme o observado na tabela 4, os resultados das provas bioquímicas efetuadas nas espécies de Bacillus spp, isoladas de amostras provenientes de 3 indústrias produtoras de leite UHT sob Inspeção Federal, não indicaram características fenotípicas que fossem conclusivas para a determinação da espécie .

A identificação da espécie do Bacillus foi determinada, preliminarmente, por prova de Espectroscopia Infra-Vermelha à Transformada Fourier, conforme apresentada na tabela 5.

As cepas 4 e 5 foram também preliminarmente identificadas pela técnica de FT-IR como Bacillus flexus e Bacillus oleronius..

Novas colônias destas amostras foram avaliadas, sendo que após este procedimento foram isoladas 2 cepas que foram tambem identificadas, preliminarmente, como Bacillus flexus.

Na tabela 5 estas cepas são representadas pelas amostras números 6 e 7.

As amostras 8,9 e 10 também não apresentaram características que pudessem ser identificadas pelas provas fenotípicas. Entretanto através da técnica de FTIR foram consideradas como Bacillus sporothermodurans . A amostra 11 não foi identificada pela ténica de FT- IR. 
Tabela 5 - Diagnóstico molecular de cepas de Bacillus flexus isoladas de amostras de leite UHT por Espectroscopia Infra-vermelho Transformada Fourier (TF-IR), 2003

\begin{tabular}{cc}
\hline Número da amostra & $\begin{array}{c}\text { Identificação da espécie pela } \\
\text { Análise FTIR }\end{array}$ \\
\hline 1 & Bacillus flexus \\
2 & Bacillus flexus \\
3 & Bacillus flexus \\
4 & Bacillus flexus e B.oleronius \\
5 & Bacillus flexus e B.oleronius \\
6 & Bacillus flexus \\
7 & Bacillus flexus \\
8 & Bacillus sporothermodurans \\
9 & Bacillus sporothermodurans \\
10 & Bacillus sporothermodurans \\
11 & Negativo \\
\hline
\end{tabular}


Em relação ao estudo da patogenicidade das cepas de Bacillus spp isoladas, pode-se observar na tabela 6 que a inoculação do filtrado estéril nos lotes de camundongos BALB C causou em determinados lotes, efeito de apatia e sonolência nos camundongos .

Os lotes $1,2,3$, receberam o filtrado estéril de $B$. flexus, os lotes 4 e 5 foram inoculados com filtrado estéril de 2 espécies de Bacillus: $B$. flexus e $B$. oleronius. Os lotes 8,9 e 10 receberam o filtrado estéril do Bacillus sporothermodurans.

O lote 11 recebeu o filtrado de Bacillus spp o qual não teve a identificação da espécie.

A interpretação dos resultados da citada tabela foi alvo de estudo estatístico para estabelecer a necessária correlação entre a morbidade observada e a inoculação do filtrado estéril dos diversos Bacillus spp. 
Tabela 6 - Obervação da Morbidade em Lotes compostos de 10 Camundongos BALB C, após inoculação de sobrenadante estéril de culturas de $B$.flexus lotes $(1,2,3)$, culturas de $B$. flexus e $B$. oleronius (lotes 4 e 5 ) e $B$. sporothermodurans (lotes $8,9,10$ ), isolados do leite UHT, 20032004

\begin{tabular}{|c|c|c|c|c|}
\hline \multirow[t]{2}{*}{ Número do Lote } & \multicolumn{4}{|c|}{ Observação da Morbidade dos animais durante 24 horas } \\
\hline & $1^{\circ}$ hora & $3^{\circ}$ hora & $5^{\circ}$ hora & $24^{\circ}$ hora \\
\hline Lote Controle & $1 / 10$ & $2 / 10$ & $0 / 10$ & $0 / 10$ \\
\hline 1 & $1 / 10$ & $5 / 10$ & $2 / 10$ & $2 / 10$ \\
\hline 2 & $1 / 10$ & $3 / 10$ & $5 / 10$ & $5 / 10$ \\
\hline 3 & $1 / 10$ & $3 / 10$ & $3 / 10$ & $3 / 10$ \\
\hline 4 & $1 / 10$ & $2 / 10$ & $8 / 10$ & $2 / 10$ \\
\hline 5 & $1 / 10$ & $2 / 10$ & $5 / 10$ & $2 / 10$ \\
\hline 8 & $1 / 10$ & $0 / 10$ & $0 / 10$ & $0 / 10$ \\
\hline 9 & 10 & $0 / 10$ & $0 / 10$ & $0 / 10$ \\
\hline 10 & 10 & $0 / 10$ & $2 / 10$ & $0 / 10$ \\
\hline 11 & $10 / 10$ & $10 / 10$ & $10 / 10$ & $0 / 10$ \\
\hline
\end{tabular}

Nota: O número do lote corresponde ao mesmo número da amostra isolada.

As frações numéricas apresentadas representam:

- Numerador indica número de animais com alterações clínicas;

- Denominador indica o número total de animais do lote.

Para determinar se houve correlação significativa entre a inoculação dos filtrados estéreis dos Bacillus spp e a morbidade observada, foi efetuado estudo estatística. Na tabela 7 são apresentados os resultados dos testes exatos de Fisher entre o grupo controle e os grupos de camundongos Balb $\mathrm{C}$ inoculados com filtrados estéis de Bacillus spp. Os testes foram efetuados em 5 horas e 24 horas da inoculação. 
Tabela 7 - Resultados dos testes exatos de Fisher entre os lotes de camundongos BALB C controle e com os lotes inoculados com filtrados estéreis de Bacillus spp. Observações efetuadas em 5 horas e 24 horas pós inoculação, 2003

\begin{tabular}{|c|c|c|}
\hline Momento & $\begin{array}{c}\text { Comparações entre o } \\
\text { controle e os grupos } \\
\text { inoculados } \\
\end{array}$ & P-value do teste exato de Fisher \\
\hline $5^{\mathrm{a}}$ hora & Controle $1 \times$ G 1 & 0.474 \\
\hline $5^{\mathrm{a}}$ hora & Controle $1 \times$ G2 & $0.033^{*}$ \\
\hline $5^{\mathrm{a}}$ hora & Controle $1 \times$ G3 & 0.211 \\
\hline $5^{\mathrm{a}}$ hora & Controle $1 \times$ G4 & $0.001^{*}$ \\
\hline $5^{\mathrm{a}}$ hora & Controle 1 X G5 & $0.033^{\star}$ \\
\hline $5^{\mathrm{a}}$ hora & Controle 2 X G8 & - \\
\hline $5^{\mathrm{a}}$ hora & Controle 2 X G9 & - \\
\hline $5^{\mathrm{a}}$ hora & Controle 2 X G10 & 0.474 \\
\hline $5^{\mathrm{a}}$ hora & Controle 2 X G11 & $<0.001^{*}$ \\
\hline $24^{\mathrm{a}}$ hora & Controle $1 \times$ G1 & 0.474 \\
\hline $24^{\mathrm{a}}$ hora & Controle 1 X G2 & $0.033^{*}$ \\
\hline $24^{\mathrm{a}}$ hora & Controle 1 X G3 & 0.211 \\
\hline $24^{a}$ hora & Controle 1 X G4 & 0.474 \\
\hline $24^{\mathrm{a}}$ hora & Controle $1 \times$ G5 & 0.474 \\
\hline $24^{\mathrm{a}}$ hora & Controle 2 X G8 & - \\
\hline $24^{\mathrm{a}}$ hora & Controle 2 X G9 & - \\
\hline $24^{\mathrm{a}}$ hora & Controle 2 X G10 & - \\
\hline $24^{\mathrm{a}}$ hora & Controle 2 X G11 & - \\
\hline
\end{tabular}


O teste estatístico efetuado em 2 momentos após a inoculação, na $5^{a}$ e na $24^{a}$ hora, demonstra morbidade significativa na $5^{a}$ hora nos lotes que receberam a cepa $n^{\circ} 2$ de $B$. flexus; $n^{\circ} 4$ e $n^{\circ} 5$ contendo $B$. flexus e B.oleronius e cepa $n^{\circ} 11$ contendo Bacillus spp. Em relação à $24^{a}$ hora houve morbidade significativa somente o grupo que recebeu a cepa $\mathrm{n}^{\circ} 2$ de Bacillus flexus.

Não foi considerada significativa a morbidade observada nos lotes de camundongos que foram inoculados com os filtrados das cepas $n^{\circ} 1$ e $n^{\circ} 3$ que B. flexus.

Não foi observada nenhuma alteração de comportamento nos camundongos, após inoculação do filtrado estéril das cepas números 8, 9 e 10 de Bacillus sporothermodurans. A inoculação do filtrado estéril da cepa $n^{\circ} 11$ do Bacillus spp apresentou efeito citotóxico em todas as culturas celulares utilzadas.

Todos os cortes histológicos dos fígados dos camundongos BALB C tanto do lote controle quanto dos lotes inoculados foram considerado sem alterações histopatológicas. 
Tabela 8 - Observação da letalidade em lotes de 10 camundongos neonatos após inoculação de sobrenadante estéril de cultura de B.flexus $\left(10^{6} \mathrm{ufc} / \mathrm{ml}\right)$, isolado de amostras de leite UHT, 2003

\begin{tabular}{cc}
\hline Número do Lote & Mortalidade após 24 horas \\
\hline Controle & 0 \\
1 & 0 \\
2 & 1 \\
3 & 0 \\
4 & 0 \\
5 & 0 \\
\hline
\end{tabular}

Nota: O número do lote corresponde ao mesmo número da amostra isolada

$\mathrm{Na}$ tabela 8 observa-se que a mortalidade dos camundogos neonatos não apresentaram mortalidade associada à inoculação dos filtrados estéreis das cepas.

Os testes em alças ligadas de coelhos efetuadas para as amostras das cepas número 1, 2 e 3 procedentes de reclamações dos consumidores assim como as cepas números 4, 5 ,6 e 7 não apresentaram positividade para esta prova. A seguir, apresentam-se fotos do lote controle de camundongos BALB C experimento e do lote inoculado com filtrado estéril da cepa $n^{\circ} 2$ de Bacillus flexus. A seguir estão apresentadas fotos do controle e do efeito citopático do $B$. flexus em células Vero, na qual observa-se apatia e imobildade dos animais. 


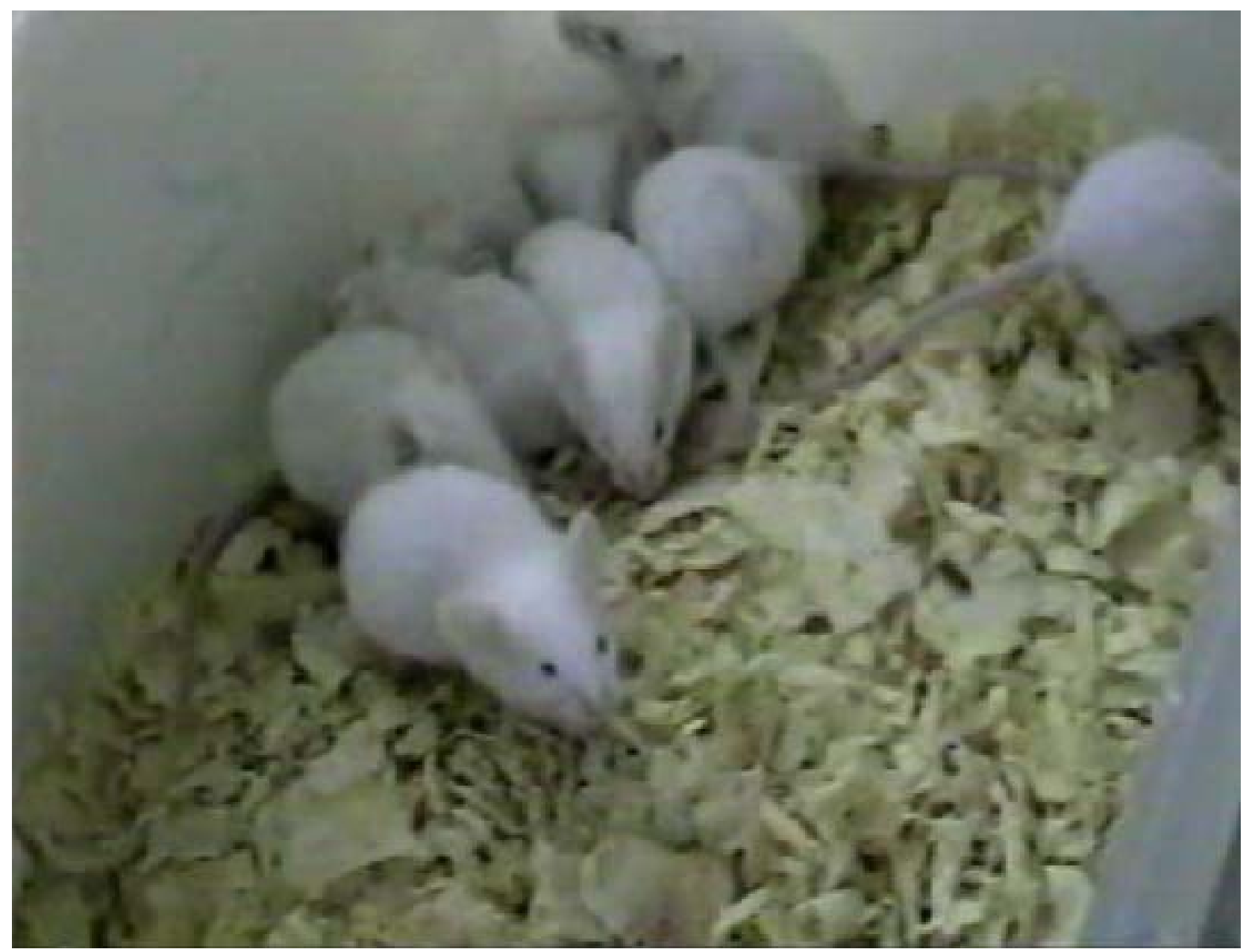

Figura 1 - Lote de camundongos BALB C - Grupo controle 


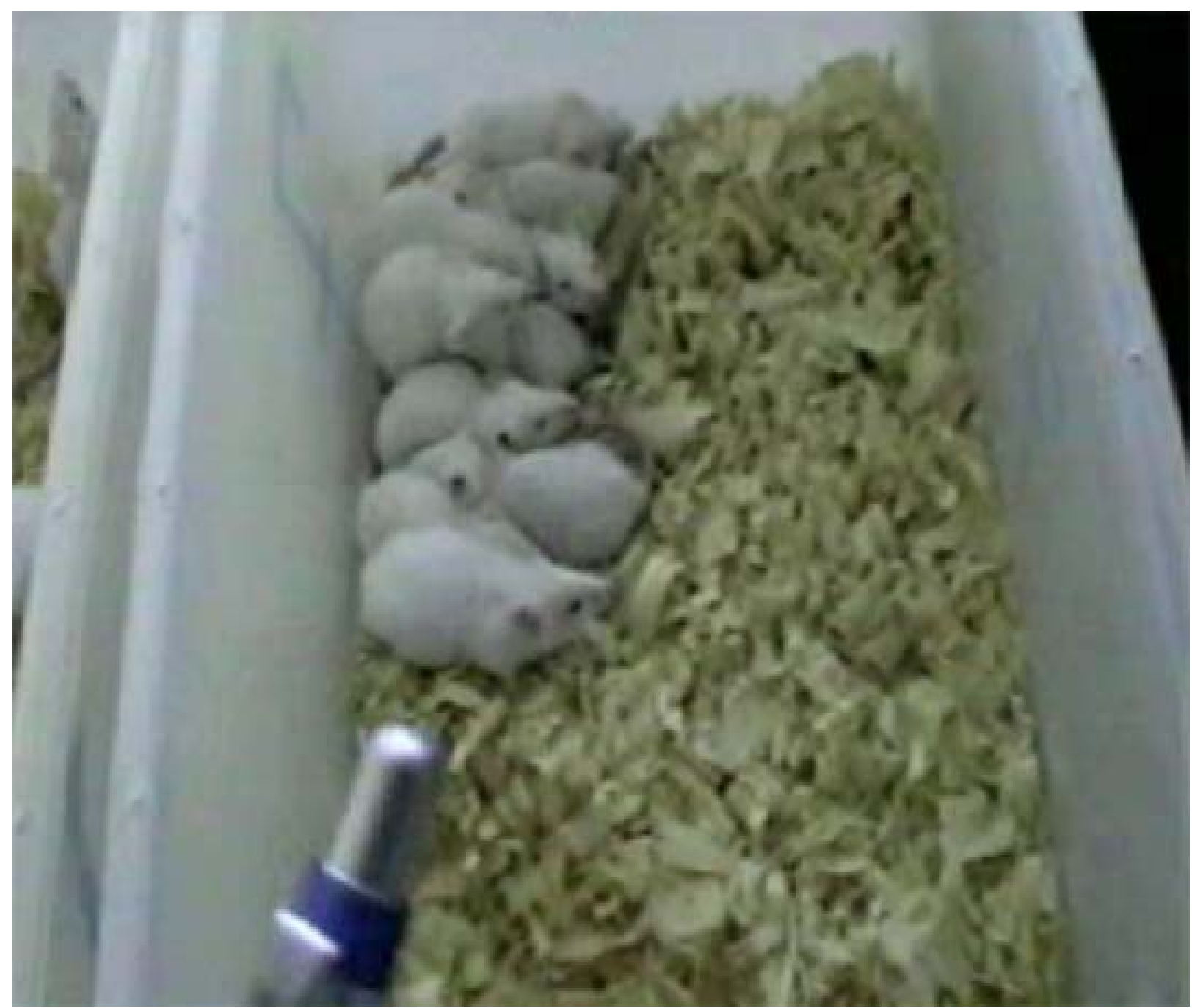

Figura 2 - Lote camundongo BALB C inoculados com filtrado estéril da cepa $\mathrm{n}^{\circ} 2$ de Bacillus flexus, após 5 horas da inoculação 
Quanto ao modelo biológico composto das culturas celulares na tabela 9, podese observar do significativo efeito citopático observado nas culturas de células Vero, HEp 2 e Fibroblastos de Embrião de Galinha, após 3 horas de inoculação dos sobrenadantes estéreis das amostras de $B$. flexus números 1, 2, 3, 6 e 7 e de $B$. flexus e $B$. oleronius números 4 e 5 .

Após aquecimento dos sobrenadantes das cepas $n^{\circ} 1,2$ e 3 a $80^{\circ} \mathrm{C}$ por 30 minutos e a seguir procedendo-se à nova inoculação em células Vero, HEp2 e Fibroblastos de Embrião de Galinha. O efeito citopático foi bloqueado após observação das culturas de células por 24 horas.

O experimento foi repetido e todos os efeitos citopáticos de todas as amostras foram novamente observados, com exceção das cepas $n^{\circ} 6$ e $n^{\circ} 7$ que não apresentaram efeito citopático para nenhuma das culturas celulares utilizadas. Não foram observados efeitos citopáticos nas culturas de células Vero, HEp 2 e Fibroblastos de Embrião de Galinha que receberam os filtrados estéreis e as amostras 8, 9 e 10.

A seguir estão apresentadas a tabela 9 e fotos do controle e do efeito citopático do B. flexus em células Vero. 
Tabela 9 - Culturas Celulares, observações de efeitos citopáticos do sobrenadante estéril de Bacillus flexus inoculados em culturas celulares Vero, HEp2 e Fibroblastos de Embrião de Galinha: Avaliação Morfológica após 3 horas de inoculação efetuada no Laboratório de Ornitopatologia do Departamento de Patologia Veterinária da Faculdade de Medicina Veterinária e Zootecnia USP, 2003

\begin{tabular}{|c|c|c|c|}
\hline $\begin{array}{l}\text { Número da } \\
\text { Amostra }\end{array}$ & $\begin{array}{c}\text { Fibroblastos de } \\
\text { embrião de } \\
\text { galinha }\end{array}$ & HEp 2 & Vero \\
\hline 1 & CEP +++ & CEP +++ & CEP +++ \\
\hline 2 & CEP +++ & CEP +++ & CEP +++ \\
\hline 3 & CEP +++ & CEP +++ & CEP +++ \\
\hline 4 & CEP +++ & CEP +++ & CEP +++ \\
\hline 5 & CEP +++ & CEP +++ & CEP +++ \\
\hline 6 & CEP $++++*$ & CEP $++++*$ & CEP $++++*$ \\
\hline 7 & CEP $+++^{*}$ & CEP $+++*$ & CEP $+++*$ \\
\hline 8 & Aus & Aus & Aus \\
\hline 9 & Aus & Aus & Aus \\
\hline 10 & Aus & Aus & Aus \\
\hline 11 & CEP+++ & CEP +++ & CEP +++ \\
\hline
\end{tabular}




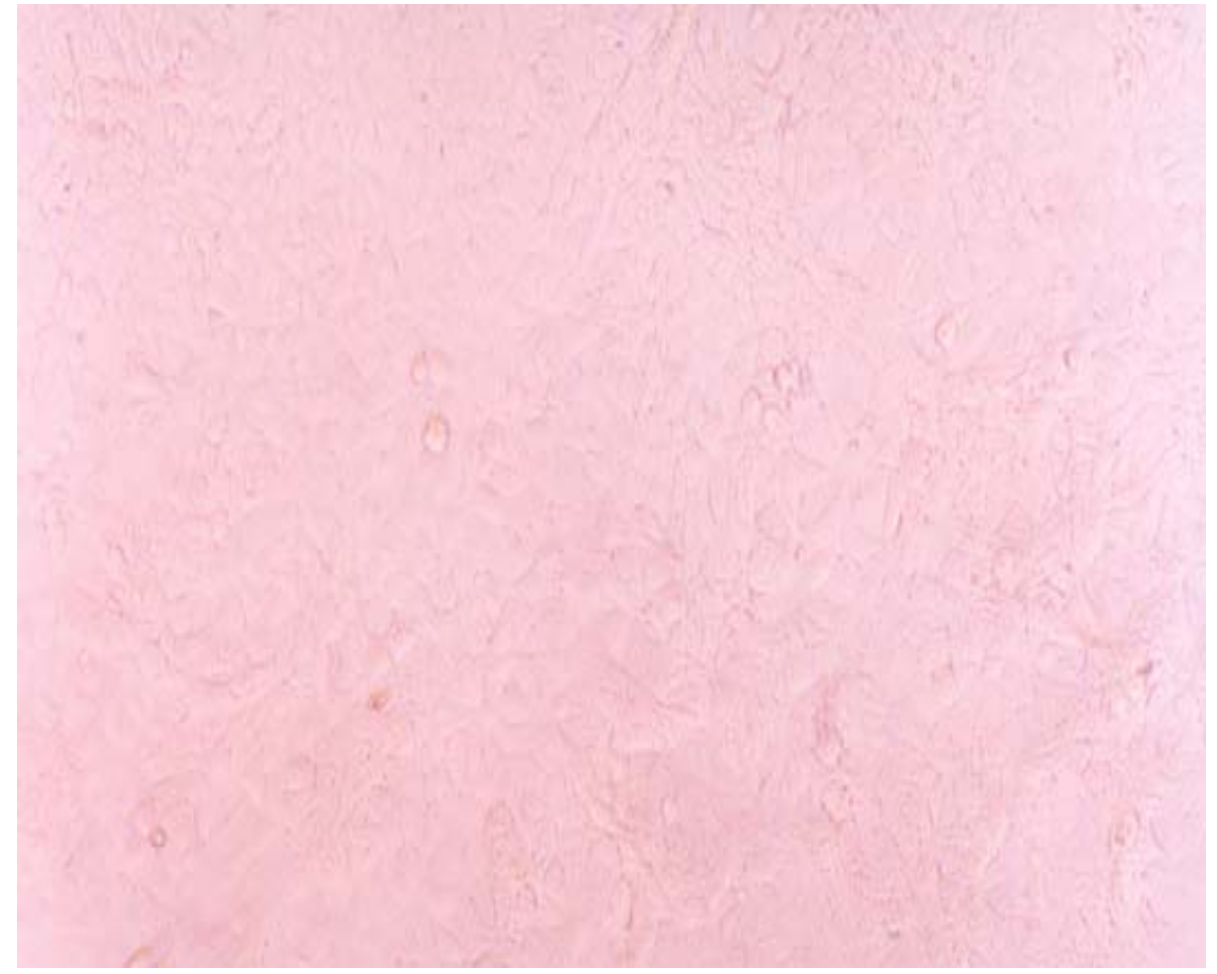

Figura 3 - Cultura de células Vero - controle 


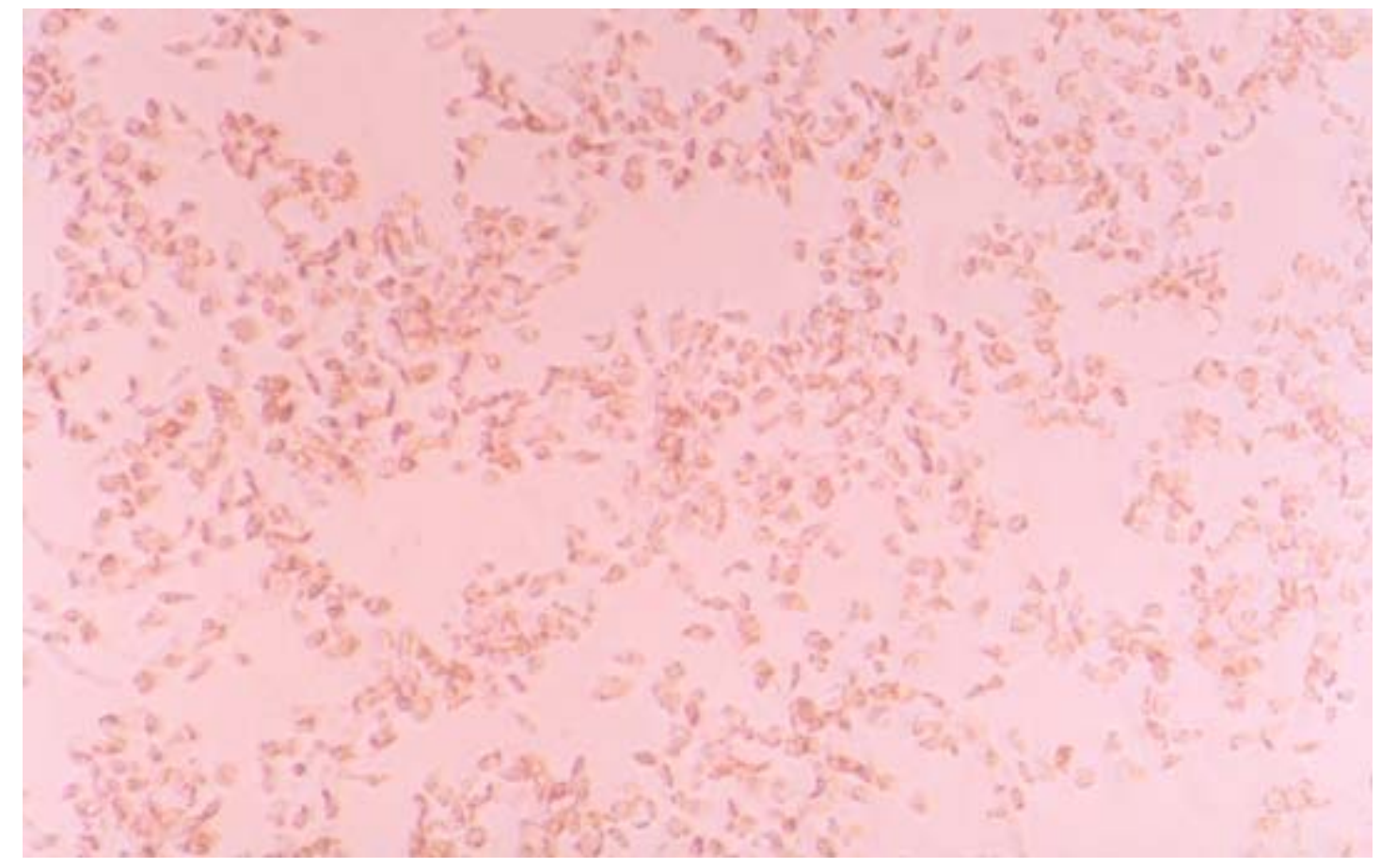

Figura 4 - Cultura de células Vero inoculada com sobrenadante estéril de Bacillus flexus - Efeito citotóxico, após 3 horas de inoculação 


\section{DISCUSSÃO}

O significado da ocorrência de $10,76 \%$ de cepas de Bacillus spp na amostragem de leite UHT do presente estudo, em níveis acima de $100 \mathrm{UFC/ml,} \mathrm{observada}$ nas indústrias sob SIF no estado de São Paulo, pode ser interpretada como o resultado de estudo de amostragem aleatória, distribuída em diferentes momentos da produção das indústrias.

A produção de leite UHT no estado de São Paulo foi de 2,3 milhões de litros por dia, em média, no ano de 2002 e primeiro semestre de 2003, conforme dados obtidos no Serviço de Inspeção de Produtos de Origem Animal da Delegacia Federal de Agricultura de São Paulo.

Considerou-se como lote, as 5 amostras analisadas de cada indústria produtora, o qual foi assim considerado tendo em vista ser uma produção dentro de condições uniformes quanto aos equipamentos, qualidade da matéria-prima e metodologia de trabalhos industriais (FORSYTHE, 2002).

Ainda que em relação aos parâmetros microbiológicos, uma amostragem de um lote de 5 unidades poderia ser considerada conclusiva, conforme o determinado pelo Regulamento Técnico de Identidade e Qualidade (BRASIL, 1997), considerou-se a presente amostragem como um resultado indicativo (BRASIL, 2001). Esta orientação baseia-se na comparação do presente estudo com os 
trabalhos efetuados pelos controles de qualidade das indústrias produtoras para se assegurarem da inocuidade de suas produções do leite UHT.

A seguir decreve-se a amostragem necessária para que o leite UHT produzido seja liberado para o consumo pelo Controle de Qualidade das empresas que o industrializam, para que seja melhor elucidado o motivo da presente amostragem ser considerada como indicativa, e não como conclusiva da qualidade do leite produzido.

Segundo Von Bockelman (1989), os trabalhos diários do controle de qualidade das indústrias produtoras para avaliação da inocuidade das partidas do leite UHT produzido baseiam-se sempre na hipótese de que a não esterilidade da embalagem do leite UHT é um acontecimento raro durante a produção. A avaliação estatística de um atributo que ocorre raramente é descrita e caracterizada pela distribuição de Poisson. Baseando-se nesta assertiva, uma das recomendações da empresa responsável pelo processamento industrial do leite UHT no Brasil é que a taxa de defectibilidade nunca deva ultrapassar 1:10.000. Portanto, para correta avaliação estatística deste raro atributo de não esterilidade, os orientadores do processo industrial consideram necessária a análise de 50 a 100 embalagens por máquina de envase por turno de produção. A totalidade desta amostragem distribui-se de uma forma aleatória ou dirigida durante todo o tempo da produção de leite UHT.

A avaliação aleatória é efetuada com colheita de uma amostra a cada 15 ou 30 minutos durante toda a produção. A amostragem é considerada dirigida quando a colheita das embalagens de leite for efetuada em determinados momentos da industrialização. Considera-se amostragem dirigida as colheitas sempre no início 
e no final da produção, além das embalagens que devem ser colhidas após a troca tanto das bobinas do material da embalagem quanto da fita de solda. Este procedimento visa detectar possíveis problemas nas selagens longitudinal ou vertical da embalagem cartonada. A amostragem dirigida poderá indicar defeitos de operação, enquanto a amostragem aleatória pode indicar defeitos do processamento ou recontaminações durante a industrialização (VON BOCKELMAN, 1989).

Portanto, após a colheita das amostras aleatórias e dirigidas, que em uma produção média de 12 horas diárias serão ao redor de 50-70 embalagens, serão incubadas a $35^{\circ} \mathrm{C}-37^{\circ} \mathrm{C}$ por 5-7 dias (BRASIL, 1997), sendo depois avaliadas quanto à esterilidade comercial. Somente após este procedimento a partida é liberada para o consumo. As avaliações dos lotes liberados são determinadas pelos controles de qualidade baseando-se na integridade das embalagens, $\mathrm{pH}$ do leite industrializado pelo processo UHT e determinações bacteriológicas (TETRA PAK. s.d.a; VON BOCKELMAN, 1989).

Em caso de ruptura da solda, por estufamento, contaminações microbiológicas ou alteração do $\mathrm{pH}$, a partida produzida será imediatamente retida para avaliação microbiológica e demais observações físicas que se fizerem necessárias. Dentre as avaliações físicas destaca-se a integridade das soldas das embalagens.

No presente estudo, no qual foram avaliadas 5 amostras por lote, considerou-se portanto a amostragem como indicativa, quando comparada à amostragem diária do processamento de 50 a 70 amostras, efetuada pelos laboratórios das 
empresas e monitorada pelos Serviços de Inspeção Federal presentes nas indústrias, que é a amostragem conclusiva sobre uma produção.

Portanto, a amostragem avaliada representa a qualidade e a segurança da produção do leite UHT no estado de São Paulo, em relação à presença de microrganismos aeróbios mesofílicos, naquele determinado momento das colheitas e pode representar uma tendência das produções estudadas.

Como uma indicação de tendência das produções, cabe considerar que indústria A apresentou 4 amostras fora dos padrões em relação a microrganismos mesófilos aeróbios.

Observa-se, sob este aspecto, que na amostra com de data de produção 07/07/2003, com contagens $>100$ UFC/ml, detectou-se a presença de B. flexus através de diagnóstico fenotípico e prova de FT-IR. A partida relativa a esta produção foi inutilizada, não tendo sido, portanto, consumida. Outras três amostras desta mesma indústria, com datas de produção de 17/11/2003, apresentaram contagens de microrganismos aeróbios mesófilos >100 UFC/ml, sendo que nesta produção foi detectada a presença de Bacillus sporothermodurans, que foi igualmente identificado tanto fenotipicamente quanto pelo método de IR-TF. A presença de Bacillus sporothermodurans, ainda que em níveis acima de $10^{3} \mathrm{UFC} / \mathrm{ml}$, não é considerado um fator de risco e, portanto, a produção pode ser liberada para o consumo (BRASIL, 2003). A discussão sobre a patogenicidade do microrganismo será retomada nesta discussão.

A indústria $H$ apresentou a avaliação na data de produção de 08/08/2003 com contagens de $>3,010^{3} \mathrm{UFC} / \mathrm{ml}$, sendo também diagnosticado como $B$. flexus pelas mesmas provas já citadas. A partida alvo deste estudo já estava 
apreendida pelo controle de qualidade da empresa produtora e foi totalmente inutilizada.

A indústria $\mathrm{J}$ apresentou 1 dos lotes com presença do Bacillus sporothermodurans no lote da data de 29/10/2003, o que não determinaria sua apreensão, conforme já foi observado anteriormente.

Em relação à prevalência de 10,76\% de contagem de microrganismos mesófilos aeróbios no presente estudo, pode-se observar que 2 partidas foram inutilizadas para o consumo, 1 relativa à Indústria $\mathrm{H}$ e outra da Indústria $\mathrm{A}$. Desta forma, a prevalência de Bacillus spp do leite colocado ao consumo pelas indústrias processadoras do estado de São Paulo foi, no presente estudo, de 7,69\%, com presença de Bacillus sporothermodurans em 6,15 \% destas avaliações.

A partir destas observações pode-se concluir que houve uma evolução no processamento UHT no nosso meio, quando comparadas às diversas publicações.

Embora o trabalho de Shochen-Iturrino, Nader Filho e Dimestein (1996), que detectaram a presença de $6,25 \%$ de presença de Bacillus spp no leite UHT analisado na região de Ribeirão Preto, possa indicar o contrário do que está sendo afirmado, cabe ressaltar que esta prevalência poderia ser maior sob a ótica dos conhecimentos atuais. Esta observaçâo baseia-se no fato de que naquele estudo utilizou-se Agar Padrão para as contagens de microrganismos mesófilos aeróbios. Estudos e documentos legais publicados recentemente orientam para a utilização de meio de enriquecimento $\mathrm{BHI}$, no qual resultados mais significativos são conseguidos em relação à determinação de Bacillus spp em leite UHT (BRASIL, 2000; ZARCACHENCO, 1996). Ainda, observa-se 
significativa melhoria se compararmos ao trabalho de Zarcachenco (1999), que detectou percentual de $45 \%$ de presença de Bacillus spp, que foi considerado como B. sporothermodurans tendo em vista que as espécies estudadas apresentaram perfil, na prova de PCR, muito semelhante a esta espécie. O estudo citado foi efetuado em leite UHT procedente de leite de 3 regiões do Brasil (Centro-Oeste, Sudeste e Sul). Esta possível melhoria observada na produção do estado de São Paulo pode ser interpretada tanto como avanço tecnológico do processamento UHT, quanto pela melhoria da qualidade do leite devida à publicação da Instrução Normativa 51 (IN51), que deverá entrar em vigência em julho de 2005 (BRASIL, 2002).

Considerando-se que dentre os contaminantes no nível de produção primária podem estar aqueles esporogênicos, que influenciam diretamente a qualidade do produto final (SILVEIRA et al., 1999; THEILMANN,1995), o avanço na melhoria da qualidade do leite in natura no nosso país determina uma maior qualidade dos diversos produtos lácteos aqui produzidos.

O principal alvo da Instrução Normativa 51 será a melhoria da qualidade do leite cru tipo $C$, que é considerado um produto de baixa qualidade por não apresentar padrões higiênicos relativos às contagens de microrganismos mesofílicos aeróbios. A citada Instrução Normativa 51, que a partir de julho de 2005 torna compulsória a contagem global de microrganismos e células somáticas para os diversos tipos de leite produzidos no Brasil, irá imprimir um importante avanço na qualidade higiênica e sanitária desta produção. A evolução, entretanto, já pode ser observada, conforme declaração de Velloso, do Ministério da Agricultura e Abastecimento, um dos responsáveis pela implantação das normas 
brasileiras, que afirma, após estudos de 41 mil produtores e de 2,5 milhões de amostras de leite cru por mês, que $90 \%$ dos produtores enquandram-se na nova legislação (MELO, 2003).

Portanto, a evolução que é observada no presente estudo pode ser, sem dúvida, também devida à melhoria da qualidade da matéria-prima utilizada nesta importante produção.

Comparando-se ainda os resultados deste experimento com os publicados por Ramos e Silva (2001), observamos que amostras avaliadas na plantas processadoras da capital de São Paulo mantiveram-se todas dentro dos padrões para microrganismos mesofílicos, o mesmo ocorrendo com as avaliações efetuadas destas indústrias, no consumo, quando foram utilizados como meios de cultura ágar padrão. Entretanto, foram observadas $20 \%$ de provas acima dos padrões quando foram utilizados meios de cultura $\mathrm{BHI}$ e nutriente. Estas observações apontam para significativo nível de presença de esporos no leite processado, naquele determinado momento. Portanto, este estudo confirma a afirmação anterior de que houve evolução na qualidade do leite UHT produzido no Estado de São Paulo.

Quanto à interpretação do diagnóstico efetuado e origem de Bacillus spp nas amostras de leite UHT, pode-se observar a presença Bacillus flexus tanto nas amostras provenientes de reclamações dos consumidores do Instituto Adolfo Lutz da Capital de São Paulo, quanto nas Indústrias A e H, sob Inspeção Federal do Estado de São Paulo, são observações preliminares que certamente deverão originar novos estudos para as necessárias conclusões sobre sua origem. 
Poucos estudos existem sobre este microrganismo e os relatos existentes indicam que a fonte principal desta bactéria é o solo e as fezes. (PRIEST e cols, 1987), entretanto, pode também este microrganismo ser encontrado, juntamente com outros Bacillus spp, no papel da embalagem cartonada do leite UHT (PIRTTIJARVI et al., 2001; PIRTTIJARVI, GRAEFFE, SALKINOJA-SALONEN, 1996).

Ainda que existam poucos estudos sobre a flora contaminante do papel utilizado para embalagem de alimentos e que não tenham sido determinadas as especificações legais sobre a qualidade microbiológicas do papelão ou papel utilizados para esta finalidade, a presença de Bacillus spp e Paenibacillus spp foi efetuada para avaliação do risco em relação à segurança dos alimentos contidos nestas embalagens. Dentre as várias espécies de Bacillus encontrados são citados Bacillus megaterium, B. cereus, B. pumilis, B. liqueformis e o $B$. flexus. Observou-se, naquele estudo, que a espécie isolada do B. flexus produzia enzimas que determinavam espoliação no alimento (PIRTTIJARVI, GRAEFFE, SALKINOJA-SALONEN, 1996).

O Bacillus flexus não é uma bactéria considerada como termo resistente e seu isolamento, no presente estudo, ocorreu tanto de leite procedente de indústria com processo de industrialização UHT indireto quanto de indústria com processamento direto. Ainda que sejam raros os estudos em relação à origem deste microrganismo em leite UHT, o presente trabalho pode indicar que foi originário de contaminação do processamento do leite ou ainda das embalagens cartonadas do produto. Entretanto, conclusões só poderão ser efetivadas após estudos mais detalhados durante o processamento do produto. 
Cabe considerar que a descrição deste bacilo aponta que linhagens desta espécie têm propriedades similares ao B. megaterium. Entretanto o $B$. flexus difere dos típicos membros desta espécie por possuir células menores (0,9 mmicra). Dentre as características fenotípicas, destaca-se a incapacidade de hidrolisar esculina, degradar caseína, elastina, gelatina, urease positiva, VP negativa, não reduz nitrato a nitrito.

As provas bioquímicas, efetuadas no presente trabalho, não foram conclusivas e tampouco retratam o perfil apresentado na literatura consultada. As amostras 1, 2 e 3, isoladas de leite UHT encaminhado após reclamação dos consumidores ao IAL, foram positivas para esculina enquanto que as amostras procedentes de isolamento de leite UHT das indústrias sob SIF em São Paulo apresentaram incapacidade de degradá-la. Quanto à prova de nitrato os resultados foram também irregulares quando observa-se que as amostras 3, 6 e 7 foram positivas para nitrato enquanto que as amostras 1 e 2 foram negativas. Portanto são resultados que não permitiriam conclusões sobre a espécie e reiterando desta forma as recomendações de Christiansson e Te Giftel (2000) e Priest, Goodfelow e Todd (1988), sobre a necessidade de que sejam efetuadas provas moleculares para um diagnóstico realmente seguro sobre a espécie de Bacillus. Entretanto apesar de terem sido efetuadas provas de FT-IR para auxílio do diagnóstico do Bacillus flexus, estes estudos estão sendo considerados como preliminares sendo que outras determinações, com provas de PCR, devem ser efetuadas com a finalidade de referendar o presente diagnóstico, o que não foi possível tendo em vista impossibilidade de referências positivas seguras sobre o microrganismo, para a execução da prova. 
Quanto à presença do B. oleronius, encontrado nas amostras números 5 e 6, isoladas de leite UHT das indústrias de São Paulo, não foi possível o seu isolamento, apesar de inúmeras tentativas. Quanto à sua possível origem no produto, não foram encontradas referências de sua presença em leite UHT.A menção a este microrganismo encontrada foi um estudo em têrmites, quando foi este microrganismo identificado através de PCR, sendo, a partir desta publicação, considerado uma nova espécie de Bacillus (KUHNIGK et al., 1995). Quanto aos resultados das provas bioquímicas do Bacillus sporothermodurans, identificado através da técnica de FT-IR, referentes às amostras ns 8, 9 e 10, estas cepas não apresentaram os resultados característicos, que são considerados como conclusivos pelas publicações oficiais do Ministério da Agricultura, Abastecimento e Pecuária (BRASIL, 2003). Este citado documento orienta que sejam considerados como Bacillus sporothermodurans os microrganismos que apresentem características morfológicas e tintoriais de Bacillus spp e que apresentem resultados bioquímicos de provas de nitrato negativas, glicose negativa, esculina positiva e oxidase positiva.

Os resultados obtidos no presente estudo apontam provas bioquímicas não conclusivas quando comparadas à literatura, contrapondo-se inclusive aos resultados da prova de FT-IR. As presentes observações corroboram com a afirmação de Christiansson e Te Giftel (2000) que as características fenotípicas rotineiras utilizadas na distinção das espécies de Bacillus têm pouco ou nenhum valor.

Com vistas a um diagnóstico seguro quanto à espécie de Bacillus spp, estes resultados apontam a necessidade de homologar os resultados das provas 
fenotípicas com provas de diagnóstico molecular como o PCR ou física FT-IR ou ainda qualquer outra metodologia específica, que possa realmente conduzir a um diagnóstico seguro para a liberação ou condenação de partidas de leite UHT, que venham eventualmente apresentar altas contagens de Bacillus spp durante seu processamento.

Quanto à presença de B. sporoterrmodurans nas amostras estudadas, cabe considerar que se trata de microrganismo sobrevivente ao processamento UHT, conforme relatos de Pettersson et al. (1996). Os estudos destes autores indicam que o microrganismo pode sobreviver ao processamento UHT no qual seja utilizada temperatura de $137^{\circ} \mathrm{C}$ a $142^{\circ} \mathrm{C}$ por segundos, característica do processamento indireto (TETRA PAK, s.d.a). A detecção deste microrganismo foi observada somente nas amostras provenientes de indústrias que utilizavam o processamento indireto. Portanto nossas observações corroboram com a literatura de que se trata de microrganismo termo resistente ao processamento indireto e não como um microorganismo contaminante do processo UHT.

Quanto à patogenicidade do Bacillus spp isolado no presente estudo, pudemos observar que no modelo composto de lotes de camundongos BALB C, observase que os resultados observados de morbidade dos lotes (apatia, sonolência e falta de reações), quando os camundongos foram inoculados com filtrados estéreis de culturas de Bacillus flexus na amostra 2 e culturas de Bacillus flexus e Bacillus oleronius, amostras 4 e 5 considerada como significativa pelo estudo estatístico, após 5 horas. Somente a amostra 2 com Bacillus flexus apresentou morbidade nos comundongos BALB C após 24 após da inoculação. 
Entretanto, o estudo histológico dos fígados dos camundongos inoculados não apresentou lesões anatomopatológicas. A morbidade observada poderá ser proveniente, possivelmente, de presença de toxina que tem como principal ação o sistema nervoso central, não determinando lesões .

Esta afirmação embasa-se no fato dos camundongos, além de não apresentarem lesões no fígado, recuperarem-se da ação da possível toxina, após 24 horas da inoculação indicando a total inativação de seu efeito pela sua metabolização no organismo do animal. Estudos posteriores devem ser efetuados para a caracterização da exotoxina isolada.

Os lotes de camundongos BALB $C$ que foram inoculados com $B$. sporothermodurans não apresentaram nenhum efeito clínico após observação por 24 horas.

Estes resultados corroboram com as observações de Cuthbert e Jackson ${ }^{1}$ (apud HAMMER, 2002), que não observaram mortalidade ou sinais clínicos nos animais inoculados.

1- CUTHBERT, J. A.; JAKSON, B. Inversk Research Institute, Scotland: personal comunication. 
Em relação à citoxicidade em culturas de células, observa-se que em Fibroblastos de Embrião de Galinha, HEp2 e Vero, os filtrados estéreis procedentes de Bacillus flexus e do Bacillus oleronius tanto procedentes das cepas isoladas de reclamações de consumidores do IAL/SP, quanto daquelas isoladas de amostras das indústrias de São Paulo, apresentaram citotoxicidade intensa, que já pode ser observada após 3 horas da inoculação nas culturas. A citotoxicidade é um parâmetro indicativo de presença de possível toxina secretada pela cepa em estudo (HAMMER, 2000), entretanto, não foram publicados até o presente, estudos de patogenicidade ou efeitos citotóxicos do Bacillus flexus originário de isolamento em leite UHT.

Quanto à citoxicidade dos filtrados estéreis, procedentes de amostras de Bacillus sporothermodurans, observa-se que, em culturas celulares, Vero, HEp 2 e Fibrolblastos de Embrião de Galinha, não foram observados efeitos citotóxicos após 24 horas de observação.

Esta observação corrobora com as afirmativas de Hammer (2000) que o microrganismo em questão não produz toxina e não é risco aos consumidores de leite UHT, no qual, eventualmente, possa o Bacillus sporothermodurans estar presente.

A afirmação quanto à ausência de risco ao consumidor é oficialmente emitida em texto do Laboratórios de Referência Animal do Ministério da Agricultura, Pecuária e Abastecimento (BRASIL,2003).

Neste documento orientam-se aos laboratórios, quanto a conclusões quando da detecção de Bacillus sporothermodurans no leite UHT, com as seguintes observações: 
Quando for observada somente a presença de colônias de Bacillus sporothermodurans na amostra, reportar o resultado de mesófilos aeróbios viáveis como $<0,3 \mathrm{NMP} / \mathrm{mL}$.

Sempre que for observada a presença de Bacillus sporothermodurans, fazer constar no Certificado Oficial de Análise (COA), no campo "OBS", a expressão: "Presença de Bacillus sporothermodurans".

Deverão ainda acompanhar o resultado de análise informações adicionais sobre o tipo de microrganismo encontrado (como por exemplo: cocos Gram positivos, bastonetes Gram negativos, flora mista, etc.) ou o(s) microrganismo(s) aeróbio(s) presente(s), quando identificado(s).

Portanto a presença do Bacillus sporothermodurans não é considerada como determinante para incriminar o produto quanto à sua segurança. Esta afirmação baseia-se no fato da literatura atual não considerar o referido Bacillus sporothermodurans como patogênico ou mesmo capaz de alterar as características físico-químicas do produto.

Entretanto as observações contidas no presente trabalho indicam que o diagnóstico de uma partida de leite UHT quanto à presença deste microrganismo não deverá basear-se somente nas características fenotípicas e bioquímicas das amostras.

Esta conclusão embasa-se na inconstância dos resultados bioquímicos observados durante a execução deste trabalho, corroborando com as 
observações da literatura como as de Christiansson e Te Giftel (2000) e de Priest, Goodfelow e Todd (1988). 


\section{CONCLUSÕES}

1. Em amostragem indicativa, a prevalência de Bacillus spp em leite UHT nas industrias de processamento no Estado de São Paulo foi de 7,69\%.

2. O Bacillus sporothermodurans foi encontrado e identificado através de análises fenotípicas e pela prova de espectroscopia Infra-Vermelha à Transfomada Fourier (TF-IR) em quatro das amostras $(6,15 \%)$ em uma das amostras não foi possível a identificação da espécie do Bacillus spp isolado.

3. Patogenicidade do Bacillus sporothermodurans não foi observada, após inoculação de filtrado estéril do microrganismo, em camundongos BALB C, não havendo tampouco citotoxicidade em células Vero. HEp2 e Fibroblastos de Embrião de Galinha.

4. Isolou-se Bacillus flexus das amostras de leite UHT procedente de 3 amostras de leite UHT de reclamações de consumidores, encaminhadas ao Instituto Adolfo Lutz da capital de São Paulo em 2002 e de 2 partidas de leite UHT inutilizadas para o consumo de indústrias sob SIF do Estado de São Paulo. O diagnóstico pela prova Espectroscopia Infra-Vermelha à Transfomada Fourier foi considerado como um resultado preliminar. Portanto, outros estudos deverão ser efetuados para que a espécie seja realmente confirmada. A origem deste microrganismo deverá também ser estudada com vistas à conclusões que possam ser utilizadas para prevenção de seu aparecimento no produto. 
5. As considerações acima devem ser estendidas à possível presença de Bacillus oleronius.

6. Quanto à patogenicidade da possível espécie de Bacillus flexus, observou-se morbidade aos camundongos BALB C em 1 cepa isolada a partir do leite encaminhado ao Instituto Adolfo Lutz e em 2 amostras que continham de Bacillus flexus e Bacillus oleronius, isoladas de leite UHT das indústrias.

Em modêlos biológicos compostos de camundongos neonatos e alça ligada de coelho não foram observados efeitos que denotassem efeitos de patogenicidade do filtrado estériil de B.flexus e B.flexus e B.oleronius.

Foi observada de citotoxicidade em células Vero, HEp2 e Fibroblastos de Embrião de Galinha, a partir de 3 horas de inoculação, de todos os filtrados estéreis procedentes de cepas de Bacillus flexus ou daqueles que continham Bacillus flexus e Bacillus oleronius. A amostra de Bacillus spp que não foi identificado quanto à espécie, apresentou caracteristicas de patogenicidade e citotoxicidade nos modêlos biológicos utilizados.

7. As observações contidas no presente trabalho, indicam que para um correto diagnóstico de presença de Bacillus spp em leite UHT este não deverá basearse somente nas características fenotípicas e bioquímicas das cepas.

Esta conclusão embasa-se na inconstância dos resultados bioquímicos observados durante a execução deste trabalho, corroborando com as observações da literatura sobre o assunto. Portanto, provas de diagnóstico moleculares adicionais devem ser efetuadas e serem compulsórias para a liberação de partidas de leite UHT que apresentem microrganismos aeróbios mesófilos viáveis acima dos padrões regulametares . 
8. Conclui-se finalmente a partir de todas as observações, que a produção de leite UHT do Estado de São Paulo apresentou evolução em sua qualidade microbiológica e que os Serviços de Controle e Garantia da Qualidade da empresas produtoras vem atuando, em sua grande maioria, de forma positiva na segurança desta industrialização, em sintonia com os objetivos do Serviço de Inspeção Federal do Ministério da Agricultura, Pecuária e do Abastecimento.

9. Embora o leite UHT não esteja citado como responsável por Enfermidade Transmitida por Alimentos nos últimos anos no Estado de São Paulo (CVE, 2004), é importante ampliar o seu controle com a finalidade de atualizar o processo de avaliação microbiológica e desta forma aumentar a garantia de segurança do produto.

Com este objetivo, diagnósticos moleculares devem ser introduzidos e deveriam ser compulsórios, para orientar a destinação de partidas do produto, eventualmente apreendidas pela presença de Bacillus spp em número acima dos padrões regulamentares.

Esta ferramenta adicional será de grande importância uma vez que a precisão na tipificação da espécie do Bacillus spp, poderá evitar a presença de cepas patogênicas deste Gênero no leite UHT . 


\title{
REFERÊNCIAS
}

\author{
ABLV (ASSOCIAÇÃO BRASILEIRA DE LEITE LONGA VIDA). Bacillus \\ sporothermodurans, uma proposta de solução. São Paulo, Brasil. 1997. 7p.
}

ABLV (ASSOCIAÇÃO BRASILEIRA DE LEITE LONGA VIDA). Leite Longa Vida. Estatísticas. Disponível em <www.abvl.org.br>. Acesso em 03 março 2004.

AGRESTI, A. Categorical data analysis. New York: Wiley, 1990. 558 p.

ANDRÉ, M. C. D. P. B.; SERAFIN, A. B.; RODRIGUEZ, M. A. V.; MIRANDA,R. C. Isolamento e identificação de bactérias esporuladas mesófilicas no leite UHT comercializados em Goiânia/GO .In: CONGRESSO LATINOAMERICANO DE MICROBIOLOGIA E HIGIENE DOS ALIMENTOS - COMBHAL, 5.,Águas de Lindóia. Anais.. .[S.I.: s.n.], p.119. 1998.

BRASIL. Ministério da Agricultura e do Abastecimento. Portaria n 451, de 19 de Setembro de 1997. Estabelece padrões de identidade e qualidade para o leite UHT/UAT. Diário Oficial da União[República Federativa do Brasil], Poder Executivo, Brasília, DF, 4 set. 1997.

BRASIL. Ministério da Saúde. Agência Nacional de Vigilância Sanitária. RDC n 12 de 2 janeiro 2001. Aprova regulamento técnico sobre padrões microbiológicos para alimentos. Diário Oficial da União[República Federativa do Brasil], Poder Executivo, Brasília, DF, 10 jan. 2001.

BRASIL. Ministério da Agricultura, Pecuária e Abastecimento. Instrução Normativa n 51 DE 18/09/2002. Regulamento técnico de produção de leite tipo $A$, tipo $B$, tipo $C$, leite pasteurizado e o regulamento técnico de coleta de leite cru refrigerado e seu transporte a granel. Diário Oficial da União[República Federativa do Brasil], Poder Executivo, Brasília, DF, 20 set. 2002.

BRASIL, Ministério da Agricultura, Pecuária e Abastecimento. Secretaria Nacional de Defesa Agropecuária. Departamento de Defesa Animal. Métodos Analíticos Oficiais para Análises Microbiológicas Para Controle de Produtos de Origem Animal. Cap III, p.14- 15. Diário Oficial da União[República Federativa do Brasil], Poder Executivo, Brasília, DF, 18 set. 2003. 
CDC (CENTER OF DISEASES CONTROL). Bacillus cereus - Maine.

Disponível em: <www.cdc.gov>. Acesso em: 4 nov 2003.

CHRISTIANSSON, A.; BERTILSSON, J.; SVENSSON, B. Bacillus cereus spores in raw milk: factors affecting the contamination of milk during the grazing period. Journal of Dairy Science, Suécia, v. 82, n , p. 306-314, 1998.

CHRISTIANSSON, A.; TE GIFFEL, M. C. Bacillus cereus in milk and milk products. 1. Taxonomy and Identification of Bacillus species. Bulletin of International Dairy Federation. Bruxelas, n. 357, p. 40-43, 2000.

CLAUS, D.; BERKELEY, A. Genus Bacillus. Cohn 1872. In: SNEATH, P. H. A. (Ed.) Bergeys manual of systematic bacteriology. Baltimore: Williams\& Wilkins, 1986. v. 2, p. 1105- 1140.

CLOSE. B.; BANISTER. K; BAUMANS, V; BERNOTH , E.M; BROMAGE, N.; BUNIAN, J.; ERHARDT, W.; FLERCKNELL, P.; GREGORY, N.; HACKBART,H.; MORTON, D.; WARWICK, C. Recommendations for euthanasia of experimental animals: part 2. Laboratory Animals,v.1, n. 31, p. 1-32. 1977.

CVE (CENTRO DE VIGILÂNCIA EPIDEMIOLÓGICA). Secretaria de Estado da Saúde de São Paulo. Dados estatísticos. Disponível em <www.cve.saude.sp.gov.br> Acesso em: 18 maio 2004.

ENTIS, P.; FUNG, D. Y. C.; GRIFTHIHS, M. W.; MCINTYRE,L.; RUSSEL, S. SHARPE, A. N.; TORTORELLO, M. L. Rapid methods for detection, identification and enumeration In: DOWNES, F. P.; ITO, K. (Ed.). Compendium of methods for the microbiological examination of foods. 4. ed. Washington, D. C.: APHA (AMERICAN PUBLIC HEALTH ASSOCIATION) p. 89- 95 , 311 - 315. 2001.

FERREIRA, A. J. P . Fatores de Patogenicidade de Escherichia coli de origem aviária. 121 f. 1985. Dissertação (Mestrado)- Faculdade de Medicina Veterinária e Zootecnia da Universidade de São Paulo, 1985.

FIL (INTERNACIONAL DAIRY FEDERATION) BULLETIN OF THE Recommendations for the hygienic manufacture of milk based products. International Dairy Federation, Suplement, Bélgica. n. 292, p. 29. 1994.

FORSYTHE, S. J. Microbiologia da segurança alimentar. Porto Alegre: Ed Artmed, 2002. p.176- 178.

HAMMER, P. Raw material: quality and pricing. Bulletin of the International Dairy Federation, Bélgica, n. 357, p. 4-8, 2000a.

HAMMER, P. Pathogenicity / toxocology. Bulletin of the International Dairy Federation, Bélgica, n. 357, p. 15-18, 2000b. 
HAMMER, P.; SUHREN, G.; HEECHEN, W. Pathogenicity of unknown mesophilic heat resistant bacilli from UHT- milk. Bulletin of the International Dairy Federation, Bélgica, n. 302, p. 56-57. 1995.

HANSEN, B. M.; LESER, T. D.; HENDRIKSEN, N. B. Polymerase chain reaction assay for the detection of Bacillus cereus group cells. FEMS Microbiology Letters, n. 202, p. 209- 213, 2001.

HELM, D.; LABICHISKI, H.; SCHALLEHN, G.; NAUMANN,D. Classification and identification of bacteria by Fourier- transform infrared spectroscopy. Journal of General Microbiology, n. 137, p. 69-79, 1991.

HERMAM, L.; HEYNDRICKX, M.; VAEREWIJCKK, M.; KLIJN, N. Isolation and methods of detection..Bulletin of International Dairy Federation, Bélgica, $\mathrm{n}$. 357, p. 9-14, 2000.

HINRICHS, J; KESSLER, H. G. Thermal processing of milk-processes and equipament. In: INTERNATIONAL DAIRY FEDERATION. Heat induced changes in milk. 2. ed. Brussels: FIL/ IDF, 1995. p. 9-21.

$\mathrm{HUCH}, \mathrm{C}$. S., KIM, H. U. A study on the mesophilic Bacillus species occurring in korean market milk treated by UHT. Korean Journal of Dairy Science, v. 5, n. 1, p. 29-36, 1983.

JAY, J. M. Microbiologia moderna de los alimentos. 2. ed. Zaragoza: Ed. Acribia, 1981. 491 p.

KANEDA, T. Fatti acids of the genes Bacillus one example of branched- chain preference. Bacteriological Reviews, v. 41, n. 2, p. 391-418, 1977.

KLIJN, N.; HERMAN, L.; LANGEVELD, L.; WAEREWIJCK, M.; WAGENDORP, A. A.; HUEMER, I; WERKAMP, A. H. Genotypical and phenotypical characterization of Bacillus sporothermodurans strains, surviving UHT sterilisation. International Dairy Journal. n. 7, p. 421- 428. 1997.

KLIJN, N.; WAGENDORP, A.; HUEMER,I.; LAGENFELD, L.; JONG, P. Heat resistance. Bulletin of International Dairy Federation, Bruxelas, n. 357, p. 1920, 2000.

KUHNIGK, T.; BORST, A. M.; BREUNIG, A.; KONIG, H.; COLLINS, M. D.; HUTSON, R. A.; KAMPFER, P. Bacillus oleronius sp.nov., a member of the hindgut flora of the termite Reticulitermes santonenensis (Feytaud). Canadian Journal of Microbiology. n 41, p. 699-706. 1995.

LOGAN, N.; BERKELEY, R. C. W. Classification and identification of the genus Bacillus using IPI test1 In: BERKELEY, R.C.W.; GOODFELOW, M.(Ed). The aerobic endospor-forming bacteria: classifications and identification. New York: Academic Press, 1881. p.106-140. 
LOGAN, N. A.; TURNUBULL, C. B. Bacillus and recently derived genera. In: MURRAY, P. R.; BARON, E. J.; PFALLER, M. A.; TENOVER, F. C.; YOLKEN, R. H. Manual of clinical microbiology. 7. ed. Washington; ASM Press, 1999. p. 357-369.

MEIRELES, A. J. Planejamento, qualidade e globalização na indústria de laticínios. São Paulo : Editores Associados, 2000. p. 91-95.

MEIRELES, A. J.; ALVES, D. R. Importância do leite longa vida para o desenvolvimento do mercado lácteo brasileiro. Balde Branco, São Paulo., p. 18. out. 2001.

MELO, B. Qualidade do leite se ajusta à normas. Balde Branco,São Paulo, p. 34-36, out. 2003.

MIKCHA, J. M. G. Estudos de fatores de virulência de amostra de Salmonella spp isoladas de diferentes fontes. 1994. 90 f. Dissertação (Mestrado) Faculdade de Medicina Veterinária- Universidade Estadual de Londrina, 1994.

MOSSEL, D. A. A; MORENO GARCIA, B. M. Microbiologia de los alimentos. Zaragoza: Acribia, 1985. 375 p.

NAUMAN, D.; HELM, D.; LABICHISKI, H. Microbiological characterizations by FT- IR spectroscopy. Nature, v. 351, p. 81-82, maio 1991.

NOTERMANS, S. H. W.; TE GIFFEL, M. C 2. Bacillus cereus: its toxins and their significance. Bulletin of International Dairy Federation, Bruxelas, n. 357, p. 43- 45, 2000.

PEREIRA, A. I. B. ; MARTINS, S. C. S. ; ALBUQUERQUE, L. M. B. Bactérias extremamente termofílicas, em leite comercial estéril. Higiene Alimentar, São Paulo, v. 14, n. 77, p. 40-44, 2000.

PETTERSSON, B.; LEMBKE, F.; HAMMER, P.; STACKBRANDT. E; PRIEST, F. G. Bacillus sporothermodurans, a new species producing highly heat-resistant endospores. International Journal of Sistematic Bacteriology, v. 46, n. 3, p.759-764, 1996.

PIRTTIJARVI, T. S; GRAEFFE, T. H.; SALKINOJA-SALONEN, M. S. Bacterial contaminants in liquid packging boards: assessment of potential for food spoliage. Journal of Applied Bacteriology. v.4, n. 81, p. 445-58, 1996.

PIRTTIJARVI, T. S.; WALSTROM, G.; RAINEY, F. A.; SARIS, P. E.;

SALKINOJA- SALONEN, M. S. Inhibition of bacilli in Industrial starches by nisin. Journal of Industrial Microbiology \& Biotechnology, v. 3, n. 26, p.107-114, 2001. 
PRIEST, F. G; GOODFELOW, M.; TODD, C. A numerical classification of the Genus Bacillus. Journal of General Microbiology, n. 134, p. 1847-1882, 1988.

RAMOS E SILVA, E. O. T. Leite longa vida integral: avaliação de alguns parâmetros de qualidade dos leites cru e processado. $2001.122 \mathrm{f}$. Tese Doutorado em Veterinária Preventiva e Saúde Animal - Faculdade de Medicina Veterinária e Zootecnia, Universidade de São Paulo.( USP ), São Paulo, 2001.

REZENDE, N. C. M. Ocorrência de bactérias do grupo Bacillus cereus e de microrganismos indicadores em leite UHT (ultra-high-temperature) integral. 1998. 82f. Dissertação (Mestrado em Medicina Veterinária) - Faculdade de Ciências Agrárias e Veterinária, Universidade Estadual de São Paulo. Jaboticabal, 1998.

SHOKEN-ITURRINO, R. P.; NADER FILHO, A..; DIMENSTEIN, A. R. Ocorrência de bactérias esporuladas dos gêneros Bacillus e Clostridium em amostras de leite longa vida. Higiene Alimentar, São Paulo, v. 10, n. 42, p. 2527,1996 .

SILVEIRA, I. A.; CARVALHO, E. P.; TEIXEIRA, D.; BARROS, B. E. Verification of the proteolytic and lipolitic activities of the microbial flora isolated from raw milk, type B milk. Psichotrophic microrganism. Revista Latioamericana de Microbiologia, v. 2, n. 41, p. 85- 89, 1999.

SNEATH, P. H.A. SECTION 13- Endospore-forming Gram positive rods AND COCCI. In: SNEATH, P. H. A.; MAIR, N.S.; SHARPE, E.M.; HOLT, J.G.

Bergey's Manual of Systematic Bacteriology, v. 2, p. 1104- 1207, 1989.

SPIRA, W. M.; GOEPFERT, J. M; Bacillus cereus induced fluid accumulation in rabbit ileal loops. Applied Microbiology, v. 24, n. 3, p. 341-348, set.1972.

SPIRA,W. M. ; GOEPFERT, J. M. Biological characteristics of an enterotoxin produced by Bacillus cereus. Canadian Journal of Microbiology, v. 21, p. 1236- 1246, 1975.

TE GIFFEL, M. C.; BEUMER, R. R.; CHRISTIANSSON. A.; GRIFFITHS, M.W. Bacillus cereus in milk and milk products. Advances in detection, typing and epidemiology. Bulletin of International Dairy Federation, Bruxelas, n. 357, p. 47-54, 2000.

TETRA PAK. Centro de Qualidade. Controle de qualidade. São Paulo, s.d.a. 232 f. Apostila de Curso de Treinamento ao Serviço de Inspeção Federal do Ministério da Agricultura em controle de qualidade em leite UHT.

TETRA PAK, Leite longa vida. São Paulo, s. d. b, cap.9. 18 f. Apostila de Treinamento TETRA PAK. 
VAEREWIJCK, M. J. M.; DE VOS, P.; LEBBE, L.; SCHELDEMAN, P.; HOTE,B.; HEYNDRICKX, M. Ocurrence of Bacillus sporothermodurans and other aerobic spore-forming species in feed concentrate for dayri cattle. Journal of Applied Microbiology, n. 91, p. 1074- 1084,2001.

VEISSEYERE, R. Lactologia técnica. 2. ed. Zaragoza: Editorial Acribia. 1972. p. 2.

VON BOCKELMANN, B. Estatísticas de amostragem. Produtos de Longa Duração. Coletâneas de conferências proferidas nos Seminários TetraPak. p.66-68. Ed Tetra Pak. Suécia, 1989.

ZACARCHENCO, P. B. Otimização da metodologia para contagem de Bacillus sporothermodurans e sua ocorrência em leite UHT. 1999. 91 f. Dissertação (Mestrado) -Faculdade de Engenharia de Alimentos, Universidade de Campinas , Campinas, 1999. 


\begin{abstract}
ANEXOS
Anexo A - PROVAS BIOQUÍMICAS (ENTIS et al., 2001)
\end{abstract}

1- Prova de Fermentação Anaeróbica da Glicose:

A habilidade da espécie bacteriana em metabolizar a glicose anaerobicamente é determinda pela semeadura de alça de cultura em meio dextrose vermelho de fenol em tubo que será incubado em anaerobiose em jarra a $35^{\circ} \mathrm{C}$ por 24 horas. A alteração da cor de vermelho em amarelo indica que ácido foi produzido.

2- $\quad$ Redução de Nitrato:

Nitrato é usualmente reduzido à nitrito pelos membros do grupo B.cereus.

O meio com nitrato deve ser inoculado e incubado a $35^{\circ} \mathrm{C}$ por 24 horas.

Nitrito é detectado pela adição de $0,25 \mathrm{ml}$ de ácido sulfanílico e 0,25 $\mathrm{ml}$ de solução de alfanaftol. Desenvolvimento de coloração alaranjada em até 10 minutos indica apresença de nitrito.

3- $\quad$ Teste do VP:

Acetilmetilcarbinol é produzido a partir da glicose pelos membros do grupo B.cereus. O meio modificado de VP deve ser inoculado e incubado a $35^{\circ} \mathrm{C}$ por 48 horas. A presença de acetilmetilcarbinol é determinada pela adição de $0,2 \mathrm{ml}$ 
de hidróxido de potássio $40 \%$ e $0,6 \mathrm{ml}$ de solução alcoólica de alfa-naftol 5\% a $1 \mathrm{ml}$ do meio de cultura.

Nas reações positivas, a adição de pequenos cristais de creatinina produz coloração púrpura. 
Anexo B - Número mais provável (NMP) de microrganismos mesófilos aeróbios viáveis capazes de causar alteração em produtos lácteos UHT e esterelizados, pastosos e viscosos ( BRASIL, 2003)

\section{Objetivos e alcance}

Estabelecer procedimento para a determinação do NMP de microrganismos mesófilos aeróbios viáveis, com exclusão daqueles comprovadamente não patogênicos e não causadores de alterações físicas, químicas e organolépticas em produtos lácteos pastosos e viscosos;

Detectar a presença de Bacillus sporothermodurans para diferenciá-lo dos demais microrganismos mesófilos aeróbios viáveis;

Aplica-se a amostras de creme de leite e outros produtos pastosos e viscosos tratados pelo processo UHT e produtos esterilizados.

\section{Fundamentos}

\subsection{Pré-incubação}

Baseia-se na incubação das amostras em estufa a $36 \pm 1^{\circ} \mathrm{C}$ por 7 dias e posterior verificação da ocorrência de alterações das características do produto.

\subsection{Determinação do NMP}

Baseia-se na semeadura de diluições seriadas da amostra em tubos contendo caldo cérebro-coração-sal 0,65\%-extrato de levedura 0,6\% (BHI-SE), seguida de incubação a $30 \pm 1^{\circ} \mathrm{C}$ por 72 horas, com posterior repique em ágar cérebrocoração $(\mathrm{BHI})$ e ágar nutriente isento de extrato de levedura e a subseqüente identificação da flora presente.

\section{Reagentes e materiais}

Vidraria e demais insumos básicos obrigatórios em laboratórios de microbiologia de alimentos;

Ágar cérebro-coração (ABHI);

Ágar nutriente isento de extrato de levedura;

Ágar esculina;

Ágar uréia;

Caldo cérebro-coração nitrato $\left(\mathrm{BHI}-\mathrm{NO}_{3}\right)$;

Caldo cérebro-coração-sal 0,65\%-extrato de levedura 0,6\% (BHI-SE);

Caldo cérebro-coração-sal 0,65\%-extrato de levedura 0,6\% concentração dupla (BHI-SE2); 
Caldo vermelho de fenol com glicose;

Solução salina peptonada $0,1 \%$;

Reativo para oxidase (N'N'N'N'-tetrametil-parafenileno-diamina ou oxalato de para-amino-dimetilanilina) ou tiras para teste de oxidase;

Peróxido de hidrogênio 3\%;

Alfa-naftilamina 0,5\%;

Ácido sulfanílico 0,8\%;

Zinco em pó;

Etanol $70 \%$ ou Etanol $70^{\circ} \mathrm{GL}$;

Reagentes para coloração de Gram.

\section{Equipamentos}

Equipamentos básicos obrigatórios em laboratórios de microbiologia de alimentos.

\section{Procedimentos}

\subsection{Preparo da amostra}

Após pré-incubação, as amostras visualmente inalteradas devem ser agitadas por 25 vezes. Antes da abertura, desinfetar externamente as embalagens com solução desinfetante e posteriormente com etanol $70 \%$ ou etanol $70^{\circ} \mathrm{GL}$. Deixar secar.

Pesar $25 \pm 0,2 \mathrm{~g}$ ou pipetar $25 \pm 0,2 \mathrm{~mL}$ da amostra de acordo com as instruções contidas no Anexo V, "Procedimentos para o preparo, pesagem e descarte de amostras", deste Manual.

Adicionar $225 \mathrm{~mL}$ de solução salina peptonada 0,1\%.

A partir da diluição inicial $10^{-1}$, efetuar as diluições desejadas de acordo com 0 Anexo II, "Diluições e soluções", deste Manual.

\subsection{Procedimentos de controle}

Aplicar os procedimentos de controle específicos estabelecidos pelo laboratório.

\subsection{Inoculação}

Inocular $10 \mathrm{~mL}$ da diluição $10^{-1}, 1 \mathrm{~mL}$ da diluição $10^{-1}$ e $1 \mathrm{~mL}$ da diluição $10^{-2}$, separadamente, em três séries de três tubos contendo $10 \mathrm{~mL}$ de BHI-SE. Na primeira série de tubos, que foram inoculados com $10 \mathrm{~mL}$ da diluição $10^{-1}$, usar o meio com concentração dupla (BHI-SE2).

Incubar a $30 \pm 1^{\circ} \mathrm{C}$ por 72 horas.

5.4 Confirmação do crescimento 
Finalizado o período de incubação, repicar todos os tubos sobre a superfície seca de $A B H I$ e de ágar nutriente isento de extrato de levedura, estriando de forma a obter colônias isoladas.

Incubar a $30 \pm 1^{\circ} \mathrm{C}$ por até 72 horas.

\subsection{Leitura}

O crescimento nas placas será indicativo de presença de mesófilos aeróbios no tubo de origem, porém será necessária a diferenciação entre Bacillus sporothermodurans (que não é patogênico nem produz alteração do produto) e outros mesófilos aeróbios capazes de alterar o alimento. Registrar o número de tubos que apresentaram crescimento de colônias nas placas correspondentes, registrando em separado as colônias suspeitas de Bacillus sporothermodurans. Quando o crescimento bacteriano for devido à presença de esporos de Bacillus sporothermodurans na amostra em análise, será observado crescimento abundante de colônias lisas, de forma regular, com coloração entre branco e bege, com diâmetro máximo de $3 \mathrm{~mm}$, facilmente identificáveis, nas placas com ABHI.

No ágar nutriente isento de extrato de levedura, o Bacillus sporothermodurans comumente não forma colônias visíveis, porém poderão se desenvolver colônias puntiformes de coloração entre branco e bege.

Selecionar de 2 a 3 colônias correspondentes a cada um dos tubos positivos e repicar para tubos com $\mathrm{ABHI}$ inclinado.

Incubar a $36 \pm 1^{\circ} \mathrm{C}$ por até 72 horas e realizar os seguintes testes confirmatórios:

\subsection{Coloração de Gram}

Preparar esfregaço das colônias suspeitas e corar pelo método de Gram

Quando forem observados bastonetes Gram positivos, realizar a prova da catalase conforme o item 5.7.

Quando forem observados microrganismos com morfologia e características diferentes de bastonetes Gram positivos, considerar o tubo correspondente como positivo para presença de aeróbios mesófilos.

\subsection{Catalase}

Com auxílio de alça de platina, palito de madeira, bastão de vidro ou Pipeta de Pasteur, estéreis, transferir a cultura para uma lâmina ou placa de vidro contendo uma gota de peróxido de hidrogênio 3\%. Misturar o inóculo ao peróxido e observar a reação.

A não formação de borbulhas indica prova negativa para catalase. A formação de borbulhas indica prova positiva para catalase.

A maioria dos membros do gênero Bacillus apresenta reação de catalase positiva.

Quando a coloração de Gram demonstrar a presença de bastonetes Gram positivos e a prova da catalase for positiva para a cultura em teste, proceder à confirmação da presença de Bacillus sporothermodurans por meio das provas 
da oxidase, hidrólise da esculina, fermentação da glicose, redução do nitrato, produção de urease e crescimento em anaerobiose, conforme abaixo descrito.

\subsection{Oxidase}

Usando alça de platina, Pipeta de Pasteur, palitos de madeira ou de plástico descartáveis, estéreis, realizar a prova da oxidase, espalhando a cultura sobre papel filtro impregnado com o reativo ou sobre tiras de papel com reativo para oxidase, comercialmente disponíveis.

Fazer a leitura em 10 a 20 segundos. Após esse tempo, reações falso positivas podem ocorrer.

O aparecimento de cor azul (N'N'N'N'-tetrametil-parafenileno-diamina) ou vermelho intenso (oxalato de para-amino-dimetilanilina) é indicativo de reação positiva.

Não utilizar alças de níquel-cromo ou alças de aço inoxidável para realizar a prova de oxidase, pois traços de óxido de ferro na superfície flambada pode produzir reação falso positiva.

O Bacillus sporothermodurans apresenta reação de oxidase positiva.

\subsection{Crescimento em anaerobiose}

Inocular a cultura em tubos de $\mathrm{ABHI}$ inclinados e incubar em jarra de anaerobiose a $36 \pm 1^{\circ} \mathrm{C}$ por $72 \mathrm{~h}$.

O Bacillus sporothermodurans não cresce em anaerobiose.

\subsection{Hidrólise da esculina}

Inocular a cultura, com agulha, em tubos contendo ágar esculina inclinado. Incubar a $36 \pm 1^{\circ} \mathrm{C}$ por até 72 horas.

A hidrólise da esculina é evidenciada pelo enegrecimento do meio.

O Bacillus sporothermodurans hidrolisa a esculina.

\subsection{Fermentação da glicose}

Semear tubos de caldo vermelho de fenol-base adicionados de glicose. Incubar a $36 \pm 1^{\circ} \mathrm{C}$ por até 72 horas.

A viragem de cor do indicador vermelho de fenol para amarelo indica a fermentação do açúcar presente.

O Bacillus sporothermodurans não fermenta a glicose.

\subsection{Redução de nitrato}

Inocular a cultura, com alça, em tubos contendo caldo $\mathrm{BHI}-\mathrm{NO}_{3}$. Incubar a $36 \pm 1^{\circ} \mathrm{C}$ por 72 horas.

Após incubação, adicionar aos tubos 0,5 a $1 \mathrm{~mL}$ de alfa naftilamina 0,5\%, e 0,5 a $1 \mathrm{~mL}$ de ácido sulfanílico $0,8 \%$.

O aparecimento de coloração rosa indica positividade para redução de nitrato. 
Quando não houver desenvolvimento de coloração, adicionar ao tubo alguns miligramas de pó de zinco. Nesta situação, o aparecimento de coloração rosa indica reação negativa enquanto que o não desenvolvimento de cor indica positividade.

O Bacillus sporothermodurans não reduz o nitrato à nitrito.

\subsection{Prova da uréase}

Inocular com alça a superfície de placas ou tubos com ágar uréia previamente preparadas.

Incubar a $36 \pm 1^{\circ} \mathrm{C}$ por até 72 horas.

Observar o crescimento com mudança de coloração para rosa intenso, o que indica positividade para produção de urease.

O Bacillus sporothermodurans não produz urease.

\section{Resultados}

Considerar positivos os tubos que apresentaram crescimento de outras bactérias diferentes do Bacillus sporothermodurans e considerar como negativo quando não for observado crescimento de colônias nas placas e quando o crescimento observado for confirmado como sendo somente de Bacillus sporothermodurans. A partir dos resultados obtidos, consultando a tabela de NMP apropriada e seguindo as instruções contidas no Anexo III, "Procedimentos básicos de contagem", deste Manual, calcular o número mais provável de microrganismos mesófilos aeróbios viáveis presentes na amostra em análise.

Quando for confirmada a presença de Bacillus sporothermodurans juntamente com outros mesófilos na amostra, deverão ser excluídos os tubos que continham apenas Bacillus sporothermodurans para o cálculo final do NMP de microrganismos mesófilos aeróbios viáveis.

Quando for observada somente a presença de colônias de Bacillus sporothermodurans na amostra, reportar o resultado de mesófilos aeróbios viáveis como $<0,3 \mathrm{NMP} / \mathrm{mL}$.

Sempre que for observada a presença de Bacillus sporothermodurans, fazer constar no Certificado Oficial de Análise (COA), no campo "OBS"., a expressão: "Presença de Bacillus sporothermodurans".

Deverão ainda acompanhar o resultado de análise informações adicionais sobre o tipo de microrganismo encontrado (como por exemplo: cocos Gram positivos, bastonetes Gram negativos, flora mista, etc.) ou o(s) microrganismo(s) aeróbio(s) presente(s), quando identificado(s).

Os resultados da análise de NMP de microrganismos mesófilos aeróbios viáveis a $30^{\circ} \mathrm{C}$ por 72 horas em produtos lácteos UHT e esterilizados, pastosos e viscosos, devem ser expressos em: NMP/g.

$\mathrm{O}$ resultado da análise de pré-incubação a $36^{\circ} \mathrm{C}$ por 7 dias deve ser expresso como "alterado" ou "sem alteração". 